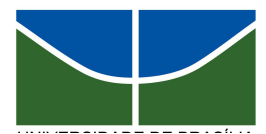

UNIVERSIDADE DE BRASÍLIA

Centro de Excelência em Turismo

Pós-graduação Lato Sensu

Curso de Especialização em Formação de Professores em Turismo

\title{
AÇÕES DE COMUNICAÇÃO EM UM HOTEL DE REDE INTERNACIONAL
}

Renata Ferro de Godoy

Orientador: Prof. Dr. Gilson Zehetmeyer Borda

Brasília - 2009 
UNIVERSIDADE DE BRASÍLIA

Centro de Excelência em Turismo

Pós-graduação Lato Sensu

Curso de Especialização em Formação de Professores em Turismo

\section{AÇÕES DE COMUNICAÇÃO EM UM HOTEL DE REDE INTERNACIONAL}

Renata Ferro de Godoy

Orientador: Prof. Dr. Gilson Zehetmeyer Borda

Monografia apresentada ao Centro de Excelência em Turismo - CET, da Universidade de Brasília - UnB, como requisito parcial à obtenção do grau de Especialista em Formação de Professores em Turismo

Brasília - 2009 


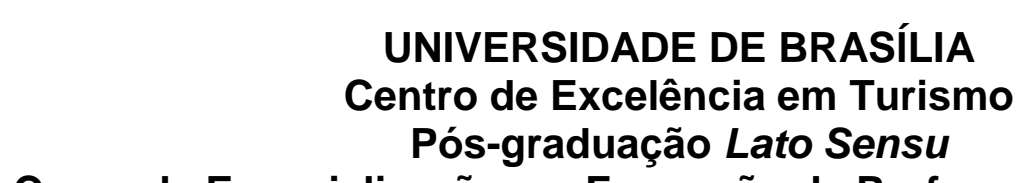

Curso de Especialização em Formação de Professores em Turismo

Renata Ferro de Godoy

Aprovado por:

Professor orientador: Dr. Gilson Zehetmeyer Borda

Professora: Msc. Joana d'Arc Bicalho Félix

Brasília, 22 de maio de 2009. 
Godoy, Renata F.

Ações de comunicação em um hotel de rede internacional /

Renata F. Godoy. - Brasília, 2009.

$x v i, 76$ f. : il.

Monografia (especialização) - Universidade de Brasília, Centro de Excelência em Turismo, 2009.

Orientador: Gilson Zehetmeyer Borda.

1. Marketing turístico. 2. Marketing mix. 3. Ações de Comunicação

I. Universidade de Brasília-CET. II. Título: uma revisão. 


\section{DEDICATÓRIA}

À minha mãe Dora (in memorian), que se faz presente em todos os dias da minha vida, sei que de seu lugar olha por mim, sofre com minhas derrotas e rejubila comigo em minhas vitórias....

Ao meu pai Roberto, que consegue ser pai e mãe e ainda companheiro, ao mesmo tempo....

...DEDICO 


\section{AGRADECIMENTOS}

À minha irmã Roberta e a minha Tia Lurdinha por compartilharem comigo todos os seus conhecimentos e "correrem" juntamente comigo para a finalização deste trabalho.

À minha irmã Daniela por toda amizade, compreensão, ajuda e por apenas existir em minha vida.

Ao meu sobrinho João Pedro, que considero como um filho, às minhas avós Waldeti e Helena e todos meus tios e primos, pelo imenso amor e extraordinário exemplo de dedicação e esperança. Pelos fortes laços e torcida por esta importante vitória.

A uma pessoa especial que apareceu em minha vida, por todo amor, pela compreensão demonstrada na realização deste trabalho e por ser responsável por muitos momentos agradáveis e felizes de minha vida.

Ao meu avô Esmeraldo (in memorian), por ter me ensinado o valor de se fazer as coisas da melhor maneira possível e por me olhar de seu lugar.

Ao meu Tio Dony (in memorian), que imagino sua vibração se estivesse aqui, por mais essa vitória em minha vida, e por dizer para eu não ter medo e seguir sempre em frente.

À minha Tia Inês, pela amizade, amor, força e palavras de incentivo em todos os momentos de minha vida.

Ao meu orientador Prof. Dr. Gilson Zehetmeyer Borda pela grande sabedoria, paciência, e principalmente por acreditar em mim, possibilitando concluir mais esta etapa da minha vida acadêmica.

Ao Programa de Pós-Graduação à Distância em Formação de Professores em Turismo da UNB por ter me concedido a chance de realizar essa especialização.

À coordenadora do curso Profa. Dra. Sandra Lestinge, pelas palavras de incentivos no momento em que mais necessitei.

As minhas "chefas" Rose e Eunice, por entenderem as minhas ausências físicas e não físicas, essa principalmente na finalização da monografia.

À todos colegas de trabalho, inclusive os "guardinhas" e a Cleuzinha pela amizade, compreensão e diversão em vários momentos.

À todos meus amigos, pela força, atenção, companheirismo e amizade durante a minha vida.

A minha amiga da "República" Aninha por toda força, compreensão e companheirismo.

A todas as pessoas que, direta ou indiretamente, contribuíram para que fosse possível a realização deste trabalho.

Em especial a Deus por estar dentro do meu coração, por me mostrar, nos momentos mais difíceis, o quanto sou forte e pela concretização desse trabalho. 


\section{RESUMO}

Este estudo teve por objetivo investigar as ações de Comunicação de Marketing aplicadas em um hotel de rede internacional no interior de São Paulo, escolhido pela sua estrutura e afinidade com o tema. Para tanto, buscou-se conhecer e analisar as ações de comunicação de marketing implementadas pelo Hotel, bem como os objetivos e resultados alcançados.

A bibliografia sobre Comunicação de Marketing para empresas de serviços, como o turismo foi utilizada de base para o presente estudo. A partir da elaboração de um roteiro contendo os principais aspectos abordados pela literatura, foram realizadas análises em documentos e dados oferecidos pelo Hotel.

A pesquisa concluiu que o Hotel tem praticado ações de comunicação de marketing junto aos seus públicos, destacando buscando a captação e fidelização. Cabe ressaltar que a venda direta é apontada como forma mais eficiente das ações de comunicação, por ser esta melhor planejada pela Rede. Em segundo seria a comunicação boca-a-boca, que além de eficaz é menos dispendiosa. Mas percebese a necessidade da elaboração e/ou alteração de estratégias de marketing que visem o aumento da demanda do Hotel.

Palavras-chave: Marketing turístico, Marketing mix. Comunicação de marketing 


\begin{abstract}
This work aimed to investigate the actions of Marketing Communication implemented in a hotel of international network in the interior of São Paulo, chosen for their structure and affinity with the subject. For this, we tried to understand and analyze the actions of marketing communication implemented by the Hotel as well as the goals and achievements.

The literature on communication in services Marketing for businesses, therefore, tourism was used as the basis for this study. From the development of a roadmap containing the main points raised by the literature, were analyzed in documents and data supplied by the Hotel.

The research concluded that the hotel has practiced actions of marketing communication with their public, emphasizing its application to capture and promote loyalty. It is important that sales is directly identified as the most efficient way of actions of communication, to be considered by the Network of more importance to planning. Second, would be the word-of-mouth, as well as effective and less expensive. But realize the necessity of establishing and / or modification of marketing strategies aimed at increasing the demand of the Hotel.
\end{abstract}

Keywords: Tourism marketing. Marketing Mix. Marketing communication. 


\section{LISTA DE FIGURAS}

Figura 1 - Elementos do marketing mix.

Figura 2 - Canais de distribuição do turismo.....................................................35

Figura 3 - Desenvolvimento dos objetivos promocionais......................................39

Figura 4 - Estatísticas de pernoites em relação ao veículo de comunicação, propaganda, que a motivou, em um Hotel do interior de São Paulo, no período

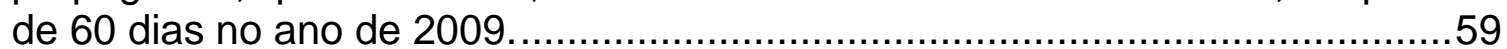

Figura 5 - Estatísticas de pernoites em relação ao veículo de comunicacao, venda direta, em um Hotel do interior de São Paulo, no periodo de 60 dias no ano de 2009. 


\section{LISTA DE QUADROS}

Quadro 1 - Empreendimentos em operação ate abril de 2004.............................15

Quadro 2 - Quantidade de apartamentos em operação até abril de 2004................16

Quadro 3 - Projeções de empreendimentos até final de 2007. ............................16

Quadro 4 - Projeções de quantidade de apartamentos até final de 2007.................16

Quadro 5 - Variáveis condicionantes do mercado consumidor...............................29

Quadro 6 - Ocupação e diária média do ano de 2008.........................................46

Quadro 7 - Estatísticas de pernoites por segmento de mercado em um Hotel do interior de São Paulo, no período de 60 dias no ano de 2009. ........................49

Quadro 8 - Estatísticas de pernoites por estado de procedencia de origem dos hóspedes em um Hotel do interior de São Paulo, no período de 60 dias no ano

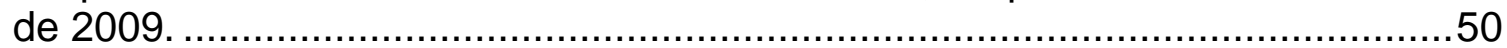

Quadro 9 - Estatíticas de pernoites em relação ao veículo de comunicação, que a motivou, em um Hotel do interior de São Paulo, no período de 60 dias no ano de 2009.

Quadro 10 - Segmentos X Canais de distribuição X Ações de Comunicação do Hotel $\mathrm{X}$.

Quadro 11 - Planejamento de ações segmentadas de comunicação........................67

Quadro 12 - Despesas previstas para o ano de 2009 com ações marketing coletivas e cooperadas 


\section{LISTA DE ABREVIATURAS E SIGLAS}

ABIH: Associação Brasileira da Indústria Hoteleira

AVIESP: Associação das Agencia de Viagens Independentes do Interior de São Paulo

AVIRP: Encontro Nacional de Agencias de Viagens - Associação das Agencia de Viagens de Ribeirão Preto e Região

FAVECC: Fórum das Agências de Viagens Especializadas em Contas Comerciais FEIARTE - Feira Internacional de Artesanato em Porto Alegre

FRANCAL - Feira Internacional de Calçados, Acessórios de Moda, Máquinas e Componentes

GDS: Global Distribuition System

INTERTUR: Feira Rio Interior de Turismo

OMT: Organização Mundial do Turismo

ONG: Organização não Governamental 


\section{SUMÁRIO}

1 INTRODUÇÃO

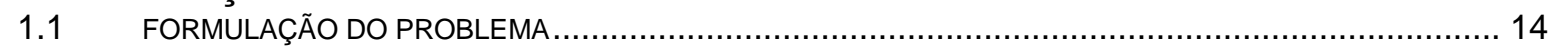

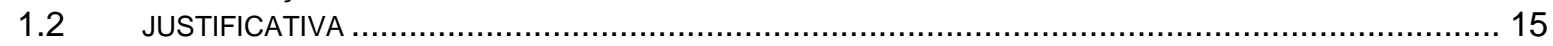

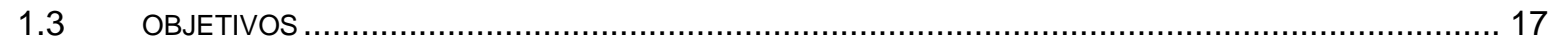

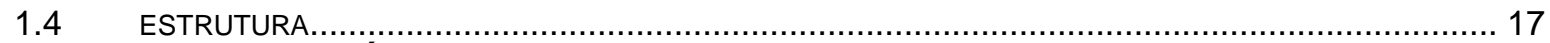

2 REFERENCIAL TEÓRICO

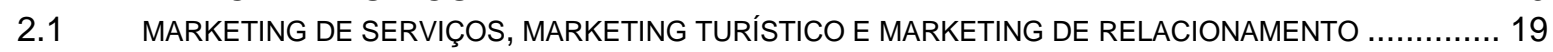

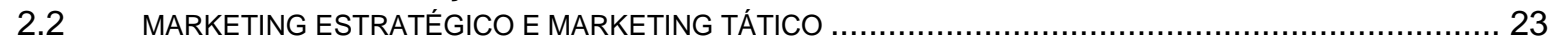

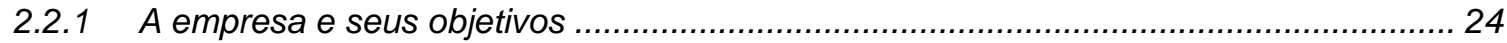

2.2.2 A descrição do ambiente interno do hotel.................................................................. 25

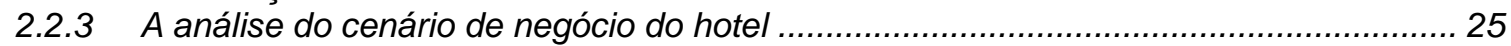

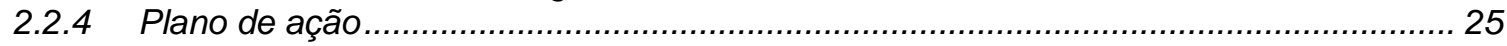

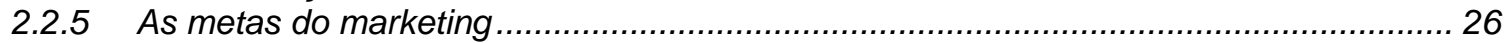

2.2.6 A descrição dos produtos e serviços oferecidos ao público alvo ...................................... 26

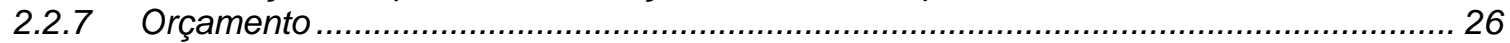

2.2.8 Os períodos e as formas de controle e a avaliação de desempenho ............................. 27

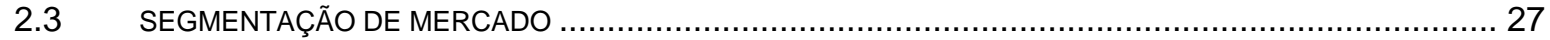

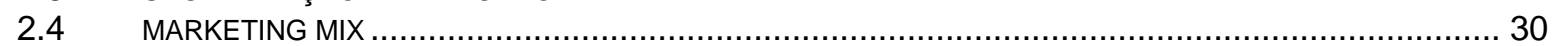

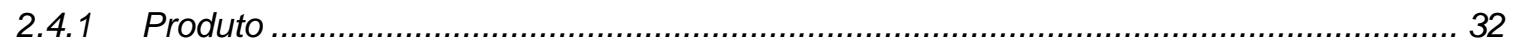

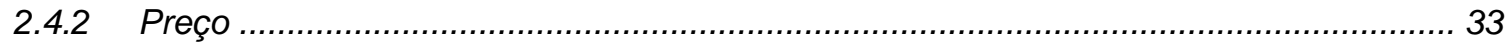

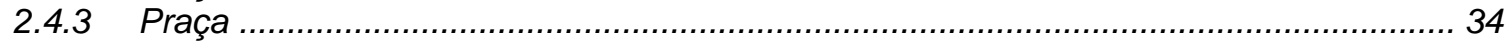

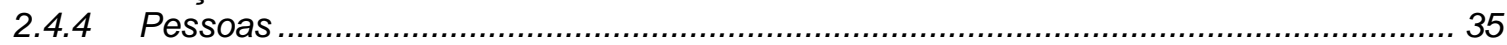

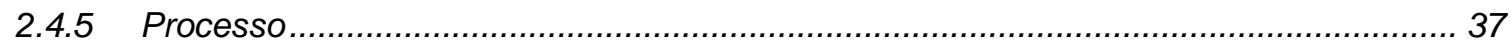

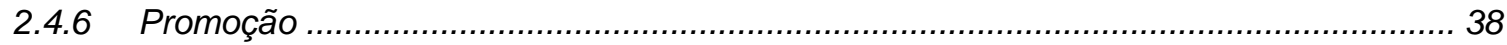

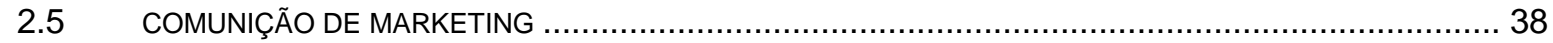

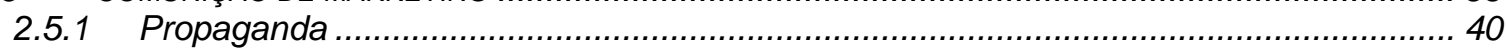

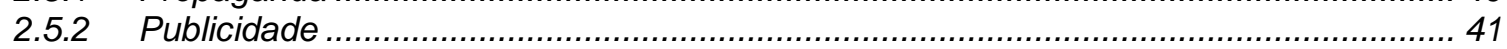

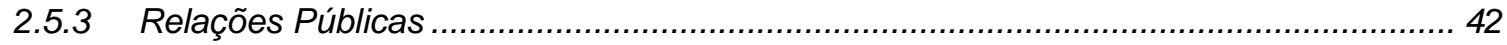

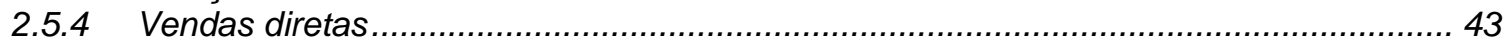

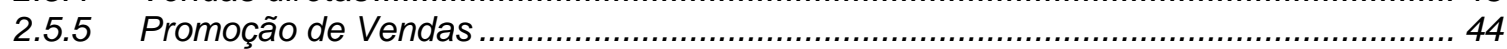

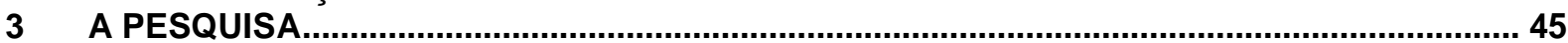

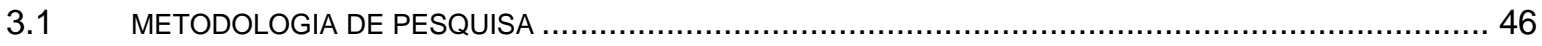

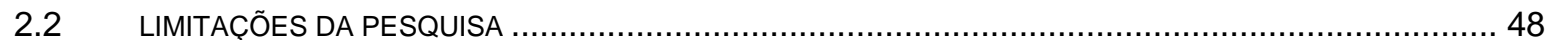

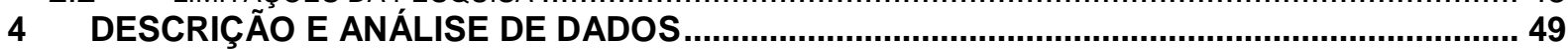

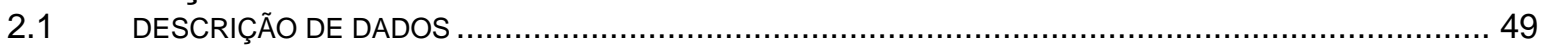

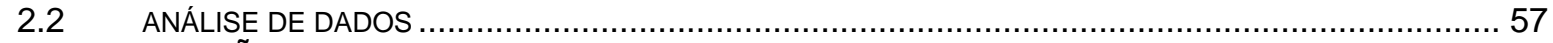

5 CONCLUSÃO

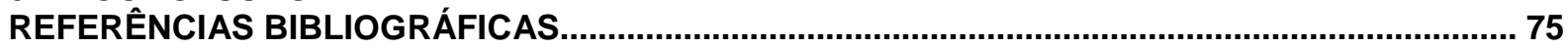




\section{INTRODUÇÃO}

Com a grande transformação que vem sofrendo a cada ano a economia mundial, as empresas necessitam ficar atentas ao ambiente que as cerca, conhecer seus pontos fortes e fracos, clientes e fornecedores, concorrentes e mercados, de modo que consigam da melhor forma possível superar desafios e aproveitar as oportunidades.

Tratando-se do turismo, por ser um dos setores da economia que mais cresce no país, as empresas desse setor carecem estar preparadas para a disputa que se apresenta, a cada dia, mais acirrada entre os concorrentes. A rede hoteleira tem se mostrado capaz de acompanhar esse crescimento, ganhando grande espaço no mercado de trabalho e mostrando ser uma das principais atividades do turismo.

Os serviços hoteleiros prestados são muito competitivos, e a busca de melhorias nesse setor é constante. A empresa hoteleira se empenha em especializar seus funcionários, adaptando-os de acordo com as necessidades do seu ambiente e das exigências dos clientes, sendo seu objetivo o de satisfazê-los com bom atendimento. Pois é o serviço prestado ao cliente o fator diferenciador entre as empresas.

Como afirmado por Ruschmann (1990, p. 25), um hotel se diferencia de outro através da atenção e do atendimento que é prestado aos seus hóspedes, "pois sem dúvida o melhor divulgador de um produto turístico é um cliente satisfeito com as experiências vividas durante sua viagem".

A hotelaria através do marketing busca a conquista e fidelização de clientes, induzindo-os a compra, como definido por Cobra (2001b, p. 272), o marketing em turismo:

[...] É criar momentos mágicos que induzam o cliente à compra. Toda atividade de apresentação de um hotel ou mesmo de uma companhia aérea tem como foco a sedução. E esse é o desafio do Marketing de Turismo: criar momentos mágicos e sedutores.

Para criar esses "momentos mágicos e sedutores", a hotelaria deve adotar instrumentos cada vez mais específicos na coleta e interpretação de dados e informações de mercado. Um desses instrumentos é o Plano de Marketing, que segundo Viera (2003, p. 149), "é o documento que descreve as estratégias de uma campanha de propaganda, onde são analisados o mercado, os concorrentes, os 
produtos ou serviços, além de definidos os objetivos a serem atingidos", ou seja, é o "documento que especifica e orienta a implementação das atividades da empresa".

Nesse Plano, a Comunicação Mercadológica precisa constituir-se como um fator estratégico, divulgando produtos/serviços da empresa e facilitando o atendimento dos objetivos do público-alvo. Para Viera (2004, p. 115), a comunicação possui papel fundamental nas empresas hoteleiras "pois ela demonstra a capacidade de trocar ou discutir idéias, de dialogar, de conversar com vistas ao bom entendimento entre as pessoas".

De acordo com Lesly (2002), a realização de ações de comunicação mercadológicas é fundamental na medida em que os gostos e desejos das pessoas não são desenvolvidos por influências de terceiros. A rede hoteleira deve investir em comunicações de marketing, pois a complexidade dos mercados e os níveis de relacionamentos entre empresa e mercado exigem dela grande troca de informações (ZENONE e BUAIRIDE, 2002).

Pensando assim, realizou-se o estudo das ações de comunicação em um Hotel de Rede Internacional destacando a aplicação de práticas de comunicação de marketing utilizadas.

\subsection{Formulação do problema}

No começo deste século, o turismo aparece como o primeiro setor da economia mundial, com altas taxas de crescimento tanto em número de turistas como no volume de gastos gerados (ANSARAH, 1999).

Com a crescente globalização de mercados vê-se aumentada a competição entre os hotéis e o decorrente desafio torna-se motivacional para sua sobrevivência. Entretanto, sobreviver, conquistar participação no mercado e, sobretudo, satisfazer as necessidades rapidamente mutáveis, não é uma tarefa fácil para os hotéis.

O profissional responsável pela área de marketing e vendas de um hotel deve estar constantemente atento ao mercado e à concorrência podendo assim garantir a qualidade de serviços, o bom atendimento, a tecnologia e outros fatores que, agregados aos serviços já prestados, fazem a grande diferença. 
Este profissional deve estar ponderado, principalmente, às ações de comunicação de seu hotel e de seus concorrentes, de modo que possa atingir de forma eficaz o segmento desejado. Ou seja, o hotel tem que implementar ações de marketing que realmente estejam dando resultado. Não adianta gastar, por exemplo, $40 \%$ da verba destinada a ações de comunicação com propaganda em determinada revista, que o público alvo não tenha acesso.

Assim, este estudo se norteará pelas seguintes questões de pesquisa: Como são desenvolvidas as ações de comunicação de um hotel de rede internacional, para a captação e fidelização de clientes? Estão as ações de comunicação integradas em uma estratégia ou são feitas de forma pontual e dispersa?

\subsection{Justificativa}

O turismo, por ser um dos segmentos que possuem grandes perspectivas de crescimento, representa um mercado de grande potencialidade de serviços para os hotéis, uma vez que esses hotéis acarretam benefícios socioeconômicos e geram uma série de empregos.

O avanço tecnológico, a evolução dos meios de transporte e de comunicação, a necessidade de tempo livre para o lazer e o aumento da população mundial, são fatores que viabilizariam o intenso deslocamento de turistas e preços acessíveis. As empresas turísticas, como os hotéis, "vêem o turismo como uma oportunidade de maximizar seus lucros, ao proporcionar os vários tipos de bens e serviços que o mercado turístico demanda". (LAGE e MILONE, 1991, p.31).

Esse crescimento pode ser notado conforme os quadros 1 a 4, apresentados por Amazonas e Goldner (2004) apud ABIH - Associação Brasileira da Indústria de Hotéis (2009):

Quadro1. Empreendimento em operação até abril de 2004.

\begin{tabular}{|l|c|}
\hline \multicolumn{2}{|c|}{ Número de Empreendimentos } \\
\hline Total de Empreendimentos: & 798 \\
\hline Hotéis: & 525 \\
\hline Flats: & 273 \\
\hline
\end{tabular}

FONTE: ABIH - Novos rumos da hotelaria (2009) 
Quadro 2. Quantidade de apartamentos em operação até abril de 2004.

\begin{tabular}{|l|c|}
\hline \multicolumn{2}{|c|}{ Número de Apartamentos } \\
\hline Total de Apartamentos: & 104.312 \\
\hline Hotéis: & 79.242 \\
\hline Flats: & 25.070 \\
\hline
\end{tabular}

FONTE: ABIH - Novos rumos da hotelaria (2009)

Quadro 3. Projeções de empreendimentos até o final de 2007.

\begin{tabular}{|c|c|}
\hline \multicolumn{2}{|c|}{ Número de Empreendimentos } \\
\hline Total de Empreendimentos: & 966 \\
\hline Hotéis: & 642 \\
\hline Flats: & 324 \\
\hline
\end{tabular}

FONTE: ABIH - Novos rumos da hotelaria (2009)

Quadro 4. Projeção de quantidade de apartamentos ate o final de 2007.

\begin{tabular}{|l|c|}
\hline \multicolumn{2}{|c|}{ Número de Apartamentos } \\
\hline Total de Apartamentos: & 131.516 \\
\hline Hotéis: & 99.077 \\
\hline Flats: & 32.439 \\
\hline
\end{tabular}

FONTE: ABIH - Novos rumos da hotelaria (2009)

Nos quadros 1 a 4 , nota-se que a diferença no número total de empreendimentos (hotéis/flats) de 2004 para 2007 é de 168 novos empreendimentos, o que representa um crescimento de 21,05\%. Mas com a crise na atual conjuntura, o setor hoteleiro deve ser afetado, mesmo tendo algumas declarações de gestores do setor afirmando o contrário. De acordo com a diretora de desenvolvimento da Hilton, Muniz (2008): "O setor já está maduro e entende que o retorno hoteleiro não acontece a curto prazo. É para daqui a cinco, dez anos. Com isso, acredito que essa crise não vai afetar". "O mercado vai continuar no mesmo ritmo considerando novos desenvolvimentos. Vamos ter menos investimentos em papel e mais em ativos, com isso as compras de segunda residência vão aumentar e 
o setor imobiliário vai crescer", disse o diretor de desenvolvimento da Hyatt, Arteaga (2008).

Os perfis dos mercados de uma forma geral, num universo altamente competitivo como o do turismo estão em constantes mudanças, fazendo com que os fatores qualidade e gestão se imponham fortemente como critério absoluto para determinar o sucesso ou fracasso de um produto ou serviço turístico.

Principalmente, porque os hotéis são importantes para o setor do turismo. E, segundo Medlik e Ingram (2002), o negócio hoteleiro, ou como se diz recentemente, a indústria da hospitalidade, cada vez mais exerce função importante na maioria dos países, pois fornecem instalações para diversos negócios, tais como reuniões e conferências, recreação e entretenimento. Portanto, os hotéis tornaramse tão importantes para a economia e sociedade quanto o comércio de bens e serviços, comunicação e transporte. Conforme os autores, devido à importância dos hotéis no crescimento do setor, estudar as formas que eles estão utilizando para a conquista de seus clientes é fundamental. E as ações de comunicações dos hotéis é uma forma de conquistar e fidelizar os clientes.

\subsection{OBJETIVOS}

O objetivo principal da monografia é analisar as ações de comunicação em um Hotel de Rede Internacional.

A investigação dessas ações deve contemplar os seguintes objetivos intermediários:

(a) Verificar se as ações de comunicação utilizadas pelo hotel são eficientes para atingir seus objetivos;

(b) Compará-las com a teoria;

(c) Analisar planejamento, implementação e resultados das ações de comunicação, bem como a relevância de cada uma deles.

\subsection{ESTRUTURA}

Esta monografia está organizada em seis capítulos, da seguinte forma: a introdução onde estão apresentados quatro itens, a saber: (1.1) Problema, (1.2) Objetivos e Delimitações, (1.3) Justificativa e (1.4) Estrutura. 
Posteriormente é apresentada a revisão da literatura, estando dividida em: (1) Marketing de serviços, turístico e de relacionamento, (2) Marketing estratégico e tático, (3) Segmentação de Mercado, (4) Marketing mix e (5) Comunicação em marketing.

$\mathrm{Na}$ seqüência estão apresentados os procedimentos que orientaram a elaboração do presente estudo. A metodologia da pesquisa e 0 tratamento dos dados. Seguindo encontram-se os resultados obtidos, com a análise dos dados.

Por último, foram apresentadas as conclusões. 


\section{REFERENCIAL TEÓRICO}

2.1 MARKETING DE SERVIÇOS, MARKETING TURÍSTICO E MARKETING DE RELACIONAMENTO

O marketing evoluiu de acordo com as pressões econômicas, sociais e empresariais. Muitas vezes é dito que se vive a era do marketing. Mas o que seria Marketing? Para Las Casas (2005, p. 26):

Marketing é a área do conhecimento que engloba todas as atividades concernentes às relações de troca, orientadas para a satisfação dos desejos e necessidades dos consumidores, visando alcançar determinados objetivos de empresas ou indivíduos e considerando sempre o meio ambiente de atuação e o impacto que essas relações causam no bem estar da sociedade.

Já de acordo com Kotler (1998, p. 32): "Marketing é um processo social e gerencial pelo qual indivíduos e grupos obtêm o que necessitam e desejam através da criação, oferta e troca de produtos de valor com outros".

Conforme os autores acima citados, conclui-se que em uma empresa é o setor de marketing quem identifica as necessidades e desejos do consumidor, determinando então mercados-alvo que o hotel pretende atender melhor e planejando serviços e produtos.

Afirmou ainda Kotler (1998), que o papel de marketing é o processo de planejamento e execução da concepção, preço, promoção e distribuição de idéias, bens e serviços, para criar trocas que satisfaçam metas individuais e organizacionais. Vender produtos ou serviços seria apenas um dos objetivos do marketing, sendo o principal estimular os clientes comprarem esses serviços ou produtos de forma satisfatória para ambas as partes.

Segundo Kuazaqui (2000), as empresas ligadas a área de serviços, devido à falta de conhecimento rejeitam ou não utilizam o marketing, que, muitas vezes, é confundido com uma ferramenta promocional e que exige um resultado rápido. O mesmo autor (2000, p. 88) ainda afirmou que "é difícil usar o marketing quando se trata de serviços, em especial atividades turísticas, principalmente pela falta de experiência dos gestores em turismo e hotelaria em nível nacional e por questões ligadas às próprias características dos serviços".

Analisando o marketing de serviços, Lara (2001) afirmou que serviço é toda a atividade ou benefício intangível, inseparável, variável e perecível, que uma 
parte pode oferecer a outra e que não resulta na posse de algum bem. $O$ ato de alugar um apartamento de um hotel envolve a compra de um serviço.

Nos serviços hoteleiros a produção e o consumo ocorrem ao mesmo tempo. Então, pela participação que o cliente tem na elaboração do serviço, o resultado obtido com o consumo do mesmo carrega um elevado grau de individualidade, pois:

A satisfação que produzirá é individualizada, diferente de uma pessoa para outra e pode ainda diferir para uma mesma pessoa, conforme o momento vivido, a maturidade, experiências anteriores ou mesmo ofertas da concorrência. A subjetividade decorre das condições em que estarão os clientes e os prestadores de serviço no momento de consumo (CASSAR, 2005, p. 205).

Para Grönroos (1995), o marketing de serviços requer uma abordagem diferenciada do marketing tradicional; é preciso abranger outros dois componentes, denominados por ele de marketing interno e marketing interativo.

Segundo Oliveira (2001, p 36), "através do marketing interno, deve-se treinar e motivar todas as pessoas e departamento envolvidos no contato com o cliente, com o propósito de que todos trabalhem como uma equipe para promover a satisfação do cliente". Já o marketing interativo significa que a qualidade do serviço percebido é altamente dependente da qualidade da interação do prestador de serviço com o usuário.

Para manter-se à frente da concorrência, é preciso diferenciar-se desenvolvendo estratégias de serviços e criando uma série de serviços que ressaltem o relacionamento com os clientes, não permitindo apenas, que a empresa diferencie sua oferta e crie um valor agregado para seus clientes, mas também ajude a manter os concorrentes distantes desse relacionamento com clientes (GRÖNROOS, 1995).

As técnicas de Marketing para a promoção de serviços turísticos e hoteleiros podem ser aplicadas direta ou indiretamente ao usuário final por meio dos canais de comunicação e vendas. A mensagem deve ser valorizada, ressaltando os fatores da marca, confiabilidade, presteza e qualidade.

Já a OMT (2001), conceituou marketing turístico como a adaptação sistemática e coordenada das políticas dos que empreendem negócios turísticos, privados ou estatais, sobre o plano local, regional, nacional e internacional, para a máxima satisfação das necessidades de certos grupos de consumidores e, assim, obter lucro certo. Vaz (1999), focando o mercado de produtos turísticos, definiu 
marketing turístico como o conjunto de atividades que facilitam a realização de trocas entre os diversos agentes que atuam, direta ou indiretamente, no mercado de produtos turísticos.

Marketing de turismo orientado para 0 consumidor significa 0 entendimento das necessidades, desejos e percepções do turista, do mesmo modo que os conhecimentos de quem são os visitantes potenciais, que serviços eles requerem enquanto estão realizando a viagem e o que eles esperam obter de toda experiência.

Ainda, segundo a OMT (2001), o conceito de gestão de marketing turístico apóia-se em três elementos básicos:

1 - Satisfação das necessidades dos turistas, sendo necessário conhecimento prévio de seus motivos e comportamentos, por meio dos estudos de mercado;

2 - Planejamento e promoção de produto turístico com elementos e características detalhadas que sejam atrativas ao consumidor, satisfaça suas expectativas, e, uma vez consumido, gere lucro para a organização que o produz;

3 - Função de intercâmbio, realizada pelos canais de distribuição que permitem o contato da demanda com a oferta, gerando lucro.

O marketing turístico torna-se relevante na elaboração e promoção de ações em Hotelaria na medida em que tem como enfoque o cliente. Ele auxilia, conjuntamente com as ações publicitárias e promocionais e as pesquisas de mercado, no conhecimento das informações necessárias para a tomada de decisões frente à demanda que pretende atingir, podendo também influenciar de maneira positiva uma comunidade.

Esse tipo de marketing é basicamente estruturado pela satisfação das necessidades do cliente, promoção e comercialização do produto turístico. Para melhor conhecer as motivações e o perfil do cliente é necessária a segmentação do mercado turístico, permitindo assim acompanhar tendências e prioridades. A sua promoção e comercialização deverão possuir visibilidade, fazendo o contato entre a oferta e a demanda turística.

Além do apoio do marketing turístico, há a necessidade da utilização do marketing de relacionamento na promoção dos serviços turísticos, pois ele cria "os pressupostos de lealdade no relacionamento entre cliente e a empresa e para isso busca desenvolver alianças eficazes e duradouras em vendas" (COBRA, 2001b, p. 271). 
De acordo com Vavra (1993), conquistar e manter clientes são os focos do marketing e para isso, é preciso desenvolver ações visando garantir a satisfação do cliente, ou seja, "entregar produtos ou serviços consistentes que atendam plenamente as necessidades e expectativas dos clientes”. Essa seria considerada a forma de se obter um relacionamento efetivo e duradouro, pois há satisfação. Cooper et al. (2001), definiu algumas características do marketing de relacionamento:

- Orientação de longo prazo. A venda é apenas o começo.

- Orientado para "nós".

- Enfoque na retenção e repetição de vendas.

- Ênfase na criação de relacionamentos positivos.

- Oferece confiança e serviços.

- Parceria e cooperação para minimizar a deserção e possibilitar relacionamentos de longo prazo.

- Perfil individual do cliente é conhecido, para que possa surgir um processo contínuo.

O marketing de relacionamento envolve muito mais que um conjunto de ações do departamento de marketing. Para Gummesson (1999, p.7 apud Crescitelli e Ikeda, 2009, p. 3), o marketing de relacionamento:

"é influenciado por diversas áreas de marketing: o marketing tradicional,
envolvendo o gerenciamento de vendas e o marketing mix (os $4 \mathrm{P}$ 's -
produto, preço, praça e promoção); serviços de marketing e a rede de
negócios industrial/comercial."

Guimarães, Milani e Crescitelli (2009) afirmaram que umas das formas de aumentar as interações do consumidor com a empresa é criar um programa de fidelização, onde ela consegue fornecer um conjunto de serviços agregados que estimulem a sua permanência como cliente, através de um conhecimento profundo das necessidades e desejos dos clientes-chave.

Analisando a fidelização de clientes novamente, remete-se à necessidade de se conhecer e entender o cliente, pois se inteirando de suas necessidades será possível oferecer o que ele procura e, assim, saber o que querem e como querem. Estas informações poderão ser facilmente obtidas através do Marketing de Relacionamento, realmente sintonizado com o mercado que pretende atingir.

Neste item, foram mencionados alguns conceitos de marketing e, nesse estudo constatou-se que o marketing, verdadeiramente, é primordial para os hotéis. 
A seguir serão abordadas formas de utilização do marketing como ferramenta de gestão.

\subsection{MARKETING ESTRATÉGICO E MARKETING TÁTICO}

De acordo com Webster (1997), o marketing envolve:

- Estratégia: marketing busca elaborar respostas eficazes aos ambientes de mercado em mudança ao definir segmentos de mercado desenvolvendo e posicionando ofertas de produtos para os mercadosalvo.

- Tática: o marketing tático lida com as atividades do dia-a-dia da gestão do produto, precificação, distribuição e comunicação de marketing como a propaganda, a venda pessoal, a publicidade e a promoção de vendas.

As estratégias de marketing são desenvolvidas e implantadas de modo que sejam combinados os elementos do marketing mix para alcançar os objetivos de curto prazo da organização, contidos no plano de marketing. Marketing estratégico está associado á aspectos de planejamento de marketing no nível negócio, ao passo que estratégia de marketing lida com aspectos de planejamento no nível funcional (FOWLER, 2002).

Segundo Santos e Mattar (2009), o envolvimento com o processo de planejamento de marketing pela primeira vez pode provocar certa dificuldade em distinguir estratégias de táticas, mas esse problema tende a desaparecer com a prática. Para evitar erros, algumas regras devem ser observadas na formulação do planejamento de marketing, quando o assunto for estratégia e tática, conforme abaixo:

1. As estratégias antecedem as táticas;

2. As estratégias são poucas, as táticas são numerosas;

3. As estratégias podem afetar o marketing de dois ou mais produtos da empresa; as táticas são exclusivas de cada produto;

4. As estratégias tendem a ter continuidade no tempo (são menos flexíveis), enquanto as táticas tendem a ser de curto prazo (são mais flexíveis);

5. Os resultados das estratégias ocorrem no médio e longo prazo: as táticas trazem resultados imediatos. 
O plano de marketing funciona em dois níveis: estratégico e tático. O plano estratégico estabelece os objetivos gerais e a estratégia de marketing. É desenvolvido com base em uma análise da situação e das oportunidades de mercado atuais. O plano de marketing tático delineia táticas específicas de marketing, incluindo as de propaganda, formas de comercialização, preços, canais e serviços.

O plano é dividido em partes que especificam cada item a ser analisado, a fim de atingir os objetivos de cada empreendimento hoteleiro.

\subsubsection{A empresa e seus objetivos}

A definição das diretrizes e objetivos organizacionais, bem como dos segmentos de atuação para a organização, partindo da orientação básica para o desempenho das tarefas organizacionais e o direcionamento do que se espera atingir é essencial para o estabelecimento do plano de marketing. De acordo com Cobra (2001a), os objetivos empresariais devem ser:

- Quantificados em termos de volume de serviços e de receita esperada;

- Especificados no tempo - por exemplo, por mês ou por ano;

- Margens de lucro por tipo de serviço prestado;

- Metas corporativas e metas departamentais, ou seja, metas da empresa como um todo e metas por departamento;

- Recursos corporativos a serem alocados por tipo de serviço, por tipo de cliente e por região em que a empresa atue;

- Fatores ambientais - anotar a influência ambiental nos negócios da empresa para o próximo ano;

- Concorrência: direta e indireta. Prever suas principais ações e influências nos negócios da empresa;

- Mercados alvo a serem atingidos no próximo ano;

- Mercado potencial - estimativa de potencial de cada mercado de interesse da empresa;

- Segmentos de mercado e alvos desejados. 
2.2.2 A descrição do ambiente interno do hotel

Com importância semelhante à do marketing e à qual se deve dar atenção especial, a informação geral de mercado, ou seja, a informação contendo dados históricos da empresa deve estar disponível, abrangendo dados de vendas / reservas / lucros, além de outros dados de natureza mais específica ou técnica do hotel.

A pesquisa de marketing interno ou endomarketing também deve incluir um estudo detalhado do marketing da empresa, tanto quanto um exame da organização no atendimento de vendas e de pós-vendas, sistemas de pesquisa de mercado, objetivo e estratégias mercadológicas atuais, sistemas de planejamento e controle.

\subsubsection{A análise do cenário de negócio do hotel}

A análise com relação ao destino ou produto turístico que será trabalhado ajuda a compor um planejamento muito bem embasado, permitindo a diminuição de futuras correções no plano. Para essa análise, devem-se levar em consideração os aspectos: o histórico da situação de mercado, a concorrência para o produto (direta e indireta), problemas que poderão se enfrentados e as carências da empresa e do consumidor.

Deverão ser analisados ainda, itens como: a situação atual e prognóstica do futuro, dados do turismo, a oferta hoteleira, o produto, e preços, a clientela e a concorrência (LARA, 2001).

\subsubsection{Plano de ação}

Nessa fase são apresentadas as metas e estratégias que deverão ser desenvolvidas para concretizar as ações de marketing. Segundo Lara (2001, p. 164):

O plano sai da teoria e toma forma de trabalho prático. É o momento de estabelecer datas para as campanhas de publicidade, promoção de vendas, participações em feiras e em exposições de turismo, bem como delegar tarefas, monitorar o desempenho das pessoas e comunicar o plano de ação a todos os participantes, para que saibam o que está para acontecer, alem de quando e quanto custará cada uma dessas ações. O ideal é que esse plano de ação seja estabelecido para cada um dos segmentos de mercado, porque dá uma visão mais ampla de como cada um será trabalhado. 


\subsubsection{As metas do marketing}

Nesta etapa são feitas abordagens amplas de marketing, que serão necessárias para atingir as metas do plano. É importante definir estas metas do planejamento de marketing a serem realizadas, para que sejam direcionadas propostas e ações, por meio de um mesmo objetivo.

Cada meta estabelecida, de acordo com Lara, 2001, poderá ser acompanhada de estratégias estabelecidas nas seguintes áreas: mercado alvo, posicionamento, linha de produto, preço, pontos de distribuição, força de vendas, serviços, propaganda, promoção de vendas, pesquisa e desenvolvimento, pesquisa de marketing.

\subsubsection{A descrição dos produtos e serviços oferecidos e o público alvo}

Nessa etapa é necessário definir e conhecer a clientela que se pretende atingir, de modo que se possa definir produtos e serviços que venham de encontro com suas necessidades e expectativas. É de fundamental importância ter visão de todas as bases de segmentação neste mercado, para poder estabelecer detalhadamente suas características, preferências, necessidades, possibilidades e disponibilidades do publico alvo.

Segundo Mota (2001), definir um produto significa conhecê-lo a fundo e identificar os atrativos, as facilidades e os acessos que o compõe. Somente após terem sido definidos produtos e clientela, poder-se-á analisar a concorrência de produtos similares verificando, então, como foi ou estão sendo realizadas as campanhas promocionais para atrair o público alvo já definido anteriormente. Além disso, todas as informações do ambiente externo devem servir de base para as tomadas de decisões.

\subsubsection{Orçamento}

O orçamento é fundamental, neste processo, para que a utilização do plano de marketing seja eficaz. Inclui quantificar todas as ações planejadas permitindo, não só obter uma visão bastante definida de quais serão os gastos, 
como também um controle eficaz e eficiente da execução do plano no dia-a-dia. Conforme Westwood (2005, p.27), "a elaboração de orçamentos define os recursos exigidos para se executar os planos e quantifica o custo e também os riscos financeiros envolvidos".

\subsubsection{Os períodos e as formas de controle e avaliação de desempenho}

Segundo Westwood (2004) é preciso controlar a implantação e revisar periodicamente o desempenho do plano elaborado. Ele deve ser monitorado na medida em que se avança, sendo recomendadas atitudes corretivas quando o desempenho não for satisfatório. Pela dificuldade de percepção do produto turístico, o controle de sua implantação é extremamente complexo, e por isso mesmo deve ser minuciosamente elaborado um sistema que consiga efetivamente fazer os controles necessários todas as etapas que o compõem. Para tanto são elementos essenciais para este controle: estabelecer calendários, organizar o sistema de informação (volume de informação necessário, base de dados mais adequada, estabelecimento de fontes internas e externas, escolha do processo de captação e análise da informação), organizar o plano de trabalho, os recursos que serão utilizados e as responsabilidades.

O planejamento de marketing, como dito anteriormente, pode ser definido como o processo de definição dos objetivos de marketing do hotel e estratégias correspondentes para atingi-los. Por objetivos de marketing entende-se participação de mercado, quantidade vendida de produto/região, grau de penetração do produto ofertado no mercado, número de usuários atendidos etc.

Para a elaboração das estratégias de marketing, também é necessário se valer da definição do público-alvo, do posicionamento e do chamado marketing mix ou 4 P's (produto, preço, praça e promoção), conforme discutido nos tópicos seguintes.

\subsection{SEGMENTAÇÃO DE MERCADO}

O processo de marketing de um hotel envolve segmentar o mercado e escolher aqueles mercados-alvo que o hotel pretende atingir e satisfazer. Deve-se formular uma estratégia ampla e definir um composto de marketing específico com 
um plano de ação para otimizar seu desempenho a longo prazo, desenvolvendo a partir de então um conjunto de controles para avaliar os resultados e operando como uma organização de aprendizado, melhorando, sempre que necessário, seu knowhow de marketing.

A segmentação de mercado é definida como:

O processo de agregação de consumidores com características homogêneas, diferenciadas de outros grupos, com o objetivo de planejar programas de marketing que se aproximem mais da satisfação de desejos e necessidades do grupo ou grupos escolhidos como mercadoalvo. Cada um destes diferentes agrupamentos é chamado segmento (Las Casas, 2005, p. 104).

O objetivo da definição dos segmentos é criar um produto ou serviço superior, que tenha vantagem competitiva em relação aos concorrentes. Definidos os desejos e necessidades dos segmentos-alvos, torna-se possível elaborar a configuração física e operacional do produto/serviço de maneira que o empreendimento possa ser lançado no mercado.

Para Whiteley (1999), a segmentação de mercado é um instrumento estratégico, que começa a ganhar força e dar condições indispensáveis para o crescimento da empresa, pois o mesmo possibilita a esta obter maior sucesso para atingir os seus objetivos.

Dessa forma, o responsável pelo marketing poderá concentrar suas ações em apenas um desses segmentos ou em um grupo deles, atuando assim no mercado-alvo. Mas nem sempre a segmentação resultará em bons negócios, pois há necessidade de que a mesma seja eficiente. (LAS CASAS , 2005).

Ainda de acordo com o autor (2005, p. 1120), as variáveis de segmentação do mercado consumidor devem ser definidas de forma objetiva e resumida, conforme o quadro 5 . 
Quadro 5. Variáveis condicionantes do mercado consumidor

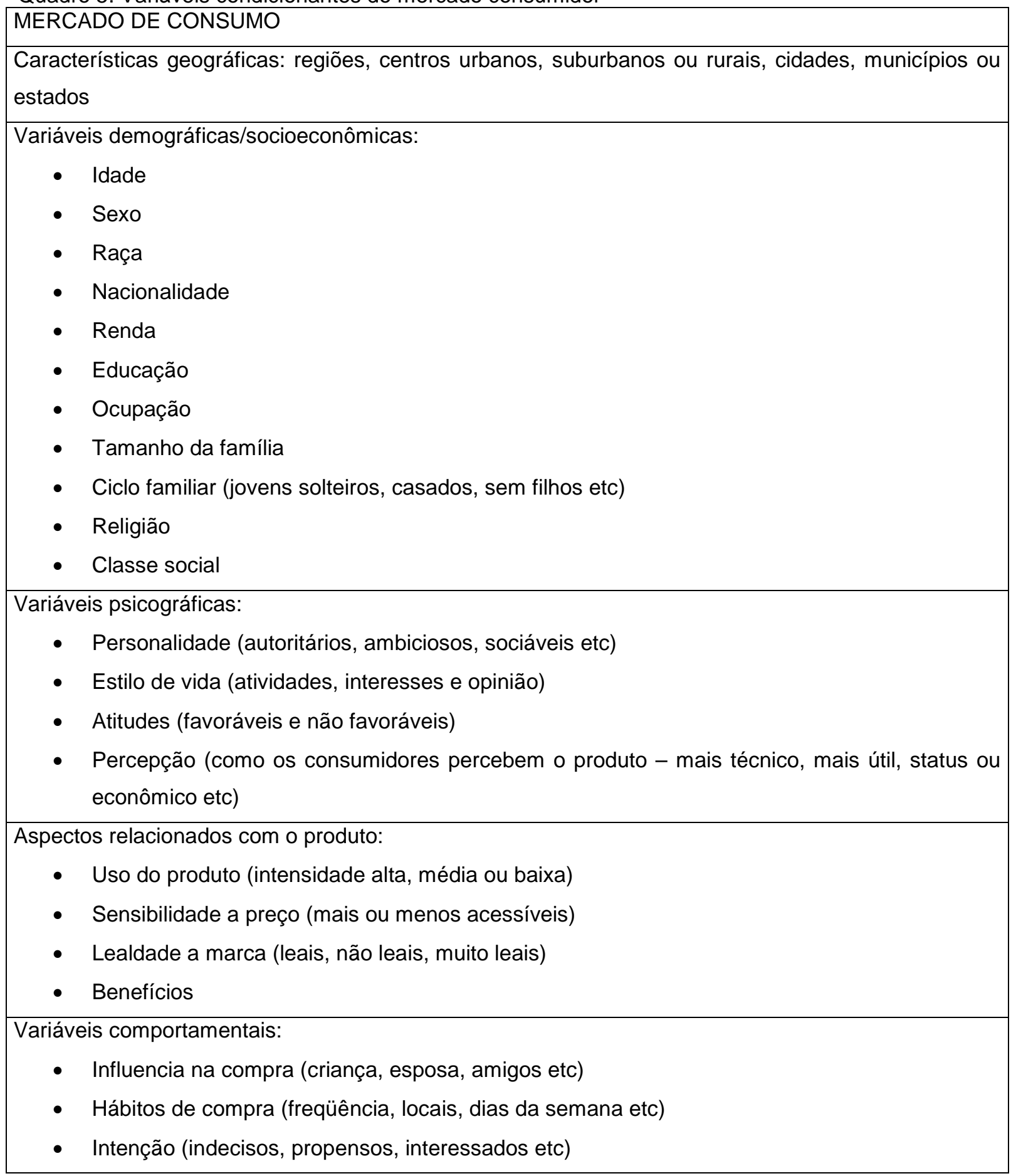

FONTE: adaptado de LAS CASAS, 2005

Middleton (2002, p. 115) afirmou que a segmentação do mercado turístico deve estar atrelada à natureza do negócio, isto é, "alguns segmentos são amplamente ditados pela localidade em que opera o negócio; outros segmentos podem ser atraídos por produtos criados e comercializados especificamente para eles". 
Em turismo, a segmentação de mercado deve observar uma ordem de prioridade, a qual o mesmo autor considera como itens mais relevantes para o mercado de viagens e turismo e comprometidos com os sistemas de informação de marketing: objetivo da viagem; necessidades, motivações e benefícios buscados pelo consumidor, comportamento do consumidor/características do uso do produto; perfil demográfico, econômico e geográfico; perfil psicográfico; perfil demográfico e preço.

Dessa forma, a segmentação do mercado turístico esta intimamente atrelada às técnicas de segmentação desenvolvidas pelo marketing e, portanto, tornar-se-á imprescindível para os produtores turísticos conhecer em detalhes as características do mercado consumidor, bem como seu comportamento e seu perfil no ato de compra e consumo.

Uma vez definido o segmento de atuação do hotel/serviço turístico, os profissionais de marketing podem seguir diversas estratégias de posicionamento, conforme os atributos específicos do produto, a ocasião de uso do produto e histórico dos concorrentes.

\subsection{MARKETING MIX}

Marketing mix ou composto de marketing é a combinação de ferramentas de marketing que são manipuladas para a realização de trocas com os membros do mercado alvo. Segundo Kotler e Armstrong (1993, p. 29), pode ser definido como "o grupo de variáveis controláveis de marketing que a empresa utiliza para produzir a resposta que deseja no mercado alvo".

As ferramentas que compõe o marketing mix, freqüentemente denominadas 4P's, correspondem ao produto, preço, promoção e praça (ou ponto de distribuição). O conhecimento das variáveis que compõe o marketing mix de uma organização é fundamental para que se possa implantar o posicionamento competitivo determinado. Posicionamento competitivo pode ser definido como "uma declaração dos mercados alvo, isto é, onde a empresa irá competir e a vantagem diferencial, ou seja, como a empresa irá competir" (HOOLEY et al., 2006, p. 35).

Os elementos do marketing mix não podem ser definidos e/ ou aplicados de forma independente. Um posicionamento que diferencie os produtos da empresa 
em termos de qualidade não terá sucesso se o preço, por exemplo, for inadequado. O resumo dos elementos do marketing mix ou dos 4 P's é sintetizado pela figura 1:

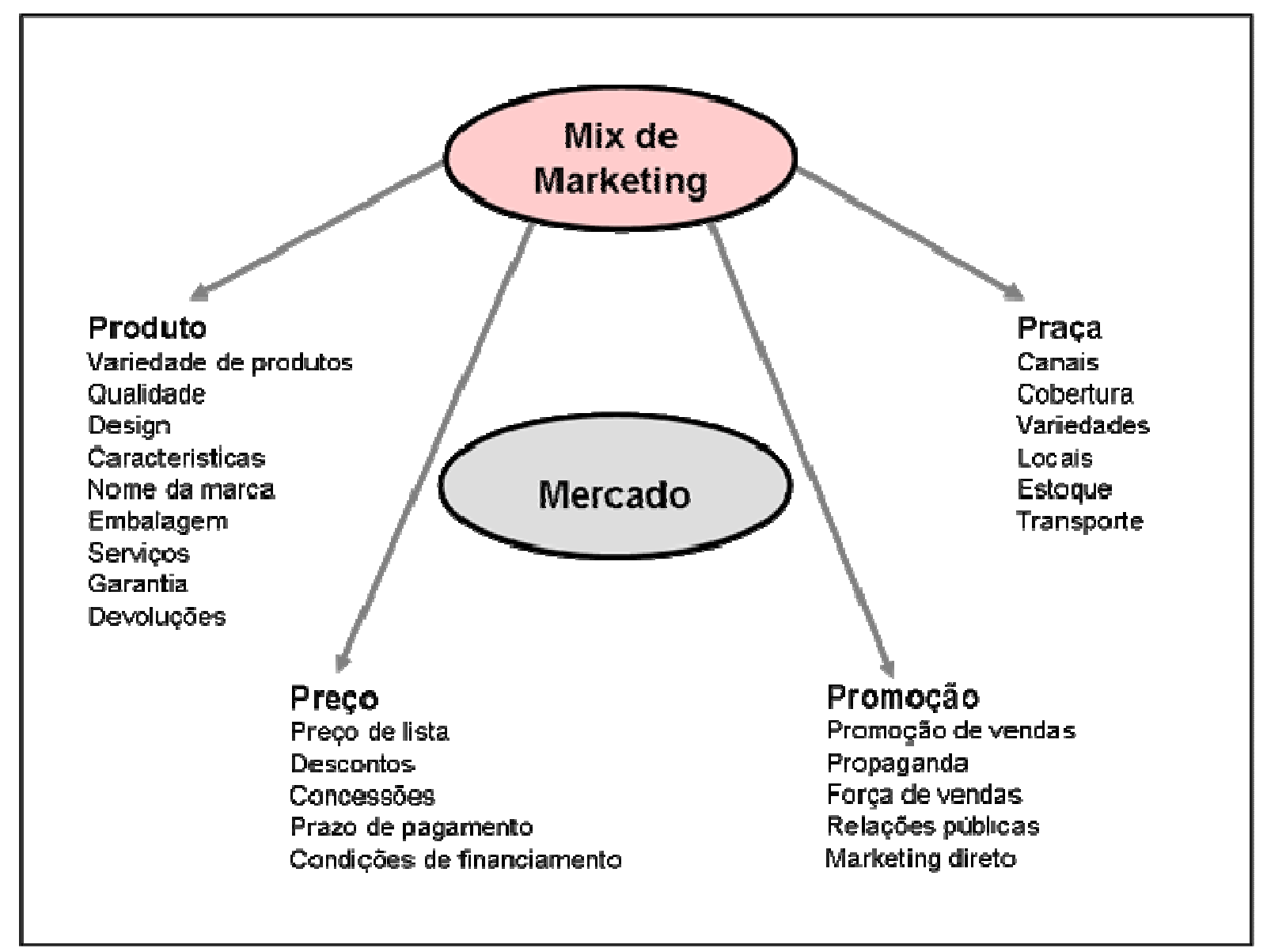

Figura 1: Elementos do marketing mix FONTE: KOTLER, 2000.

O composto de marketing ou mix de marketing, como observaram Kotler e Armstrong (1993), são todas as ações da empresa para produzir a resposta que se deseja no mercado. O conhecimento deste permite a identificação e a definição do seu comportamento e atuação em relação à concorrência, ou seja, o interrelacionamento dos elementos de marketing com 0 ambiente que cerca a organização.

Kotler (2000) atesta que as abordagens dos 4 p`s funcionam de forma satisfatória para bens, mas outros elementos exigem atenção nas empresas de serviços como, por exemplo, pessoas e processos. Em razão da maioria dos serviços ser fornecida por pessoas, a seleção o treinamento e a motivação dos funcionários podem fazer grande diferença na satisfação do consumidor. O ideal é que os funcionários mostrem competência, atenção, responsabilidade, iniciativa, 
habilidade para solução de problemas e boa vontade. E, as empresas de serviços podem escolher entre vários processos para prestar serviços.

O conhecimento das variáveis que compõe o marketing mix de uma organização é fundamental para ela implante o posicionamento competitivo determinado. Nesse caso aprofundar os conhecimentos de cada individualmente é de grande mérito.

\subsubsection{Produto}

Clientes não compram produtos; eles compram o que o produto oferecem a eles. Em outras palavras, os clientes estão menos interessados nas características técnicas do produto ou serviço do que nos benefícios que eles obtêm através da compra, uso ou consumo do produto ou serviço (HOOLEY et al., 2006).

De acordo com Kotler (1998, p. 310), "produto é algo que pode ser oferecido a um mercado para satisfazer a um desejo ou necessidade." Ele é considerado o mais importante ponto para elaboração de planejamento pela empresa. São considerados produtos os bens físicos (cama, carro etc), serviços (hotéis, concertos etc), pessoas (Ronaldo Fenômeno, Daiane dos Santos etc) e locais (Fortaleza, Brasília etc). E na tarefa de planejar o produto hoteleiro, o cliente é o principal fator, é quem deve orientar todos os passos e as ações envolvidas no planejamento de marketing.

Viera (2004, p. 78) conceituou serviço como sendo "a ação do homem em promover algo, em elaborar ou manipular algo, e com ele as pessoas alteram seu comportamento diário, suas rotinas e definem seus objetivos".

E segundo Lara (2001), algumas características dos serviços são:

- Intangibilidade: não pode ser tocada (experiências vividas);

- Inseparabilidade: produção e consumo ocorrem simultaneamente;

- Perecibilidade: serviços não podem ser estocados para venda futura;

- Variabilidade: qualidade depende das pessoas que os prestam.

Além de suas características, o produto hoteleiro tem sua essência como:

- Aparência e localização adequadas;

- Acomodações confortáveis e limpas;

- Atendimento profissional, porém gentil e agradável

E ainda produtos de suporte, ou seja, o diferencial: 
- Computador para uso do hóspede, interligado à Internet;

- Serviços de impressão e xerox;

- Informações sobre a cidade e eventos;

- Serviços de confirmação de reserva de vôo;

- Serviços eficientes de telefonia;

- Serviços de transporte para o aeroporto e eventos.

\subsubsection{Preço}

A definição do preço está muitas vezes relacionada com que o consumidor está disposto a gastar para usufruir do serviço (produto). Mas não se pode estabelecer preço tendo como base apenas o consumidor, como si só, mas sua reação quanto à concorrência.

Quanto maior for o grau de diferenciação do produto ou serviço, maior será a possibilidade de cobrar um preço mais alto. Quando existem poucas razões de diferenciação, a concorrência de preço torna-se mais forte e as vantagens de custo passam a ter importância maior (HOOLEY et al., 2006).

De acordo com Cooper et al. (2001), as influências nos preços das atividades turísticas são em razão de:

- A natureza perecível do produto, que não pode ser armazenado até uma ocasião futura, levando a várias formas de definição tática de preços e última hora.

- A alta elasticidade de preços de demanda exibida pelos mercados de férias coloca a ênfase no estabelecimento de preços em níveis corretos.

- Muitos hotéis dependem dos grandes volumes para equilibrar-se e irão renunciar a lucros rápidos para criar um fator de aproveitamento ou níveis de ocupação aceitáveis.

- O controle de custo é uma parte importante da política de preços. Muitos empreendimentos turísticos têm custos fixos altos e preços próximos do ponto de equilíbrio. Isto pode deixá-los vulneráveis ao colapso financeiro, se os custos não forem controlados.

- A demanda sazonal leva a períodos de pico e temporada baixa que exigem que o gerenciamento de demanda cuide dos problemas de capacidade temporários. 
- O preço está associado aos aspectos psicológicos de qualidade e status. É sempre importante, portanto, conhecer as formas com que os preços ou suas mudanças serão percebidos por diferentes segmentos alvo.

- Os fluxos de caixa são altos devido ao fato de que muito do pagamento por produtos turísticos é feito antes do consumo. Muitas empresas de turismo lucram com o investimento deste dinheiro.

Pode-se dizer que a definição do preço do produto depende de fatores como: concorrência, consumidor (o que interessa a ele) e a capacidade de produzir lucro. E que a realização de pesquisas de mercado é fundamental para detectar o preço que o mercado está disposto a pagar por um produto e/ou serviço e lançar um produto com o preço adequado à demanda.

\subsubsection{Praça}

"Corresponde à disponibilização, distribuição do produto ou serviço ao turista, ou seu acesso às estruturas ofertadas" (GIACOMINI FILHO, 2004, p. 221). Maximiano (2000) afirmou que a definição e o planejamento da praça compreendem as decisões sobre o canal de distribuição. $O$ cliente específico que se pretende alcançar e a distribuição física do produto ou serviço é influenciado pelo tipo de produto que será oferecido, pelo ambiente competitivo no qual ele é comercializado, pelas políticas e recursos da empresa e pelas necessidades dos consumidores.

Os canais de distribuição são vários e podem ser realizados diretamente para o usuário final, ou, através de distribuidores, representantes, varejistas. Ou seja, uma fábrica de chocolates, por exemplo, pode vender seus produtos para distribuidores e varejistas. Outras, já vendem diretamente para os consumidores finais, através de feiras e entregas domiciliares. A escolha do canal dependerá do negócio e da facilidade de distribuição dos produtos para o mercado.

As ações de marketing devem ser realizadas para o usuário final e também para todo o canal de distribuição. Fabricantes, por exemplo, possuem programas de treinamentos para vendedores e representantes de seus produtos, além de premiações. Esses programas permitem que vendedores conheçam mais sobre os produtos e, assim, adquiram maior conhecimento para o melhor desempenho na venda. 
O serviço turístico é alugado e consumido, entretanto, ele deve estar disponível e acessível aos seus clientes em potencial através de um sistema de distribuição. Este pode ser considerado o canal para ganhar acesso aos compradores potenciais do produto, ou os meios pelos quais o prestador de serviços turísticos ganha este acesso. Conforme Beni (1998), a distribuição do produto turístico é definida como um conjunto de medidas tomadas com o objetivo de levar o produto ou serviço do produtor ao consumidor. Sua realização ocorre através dos canais de distribuição, que, segundo Krippendorf (2001), é o conjunto de empresas economicamente independentes através das quais o produto, ou o direito sobre ele, é levado ao consumidor. A figura 2 representa melhor a relação de canais de distribuição na atividade turística.
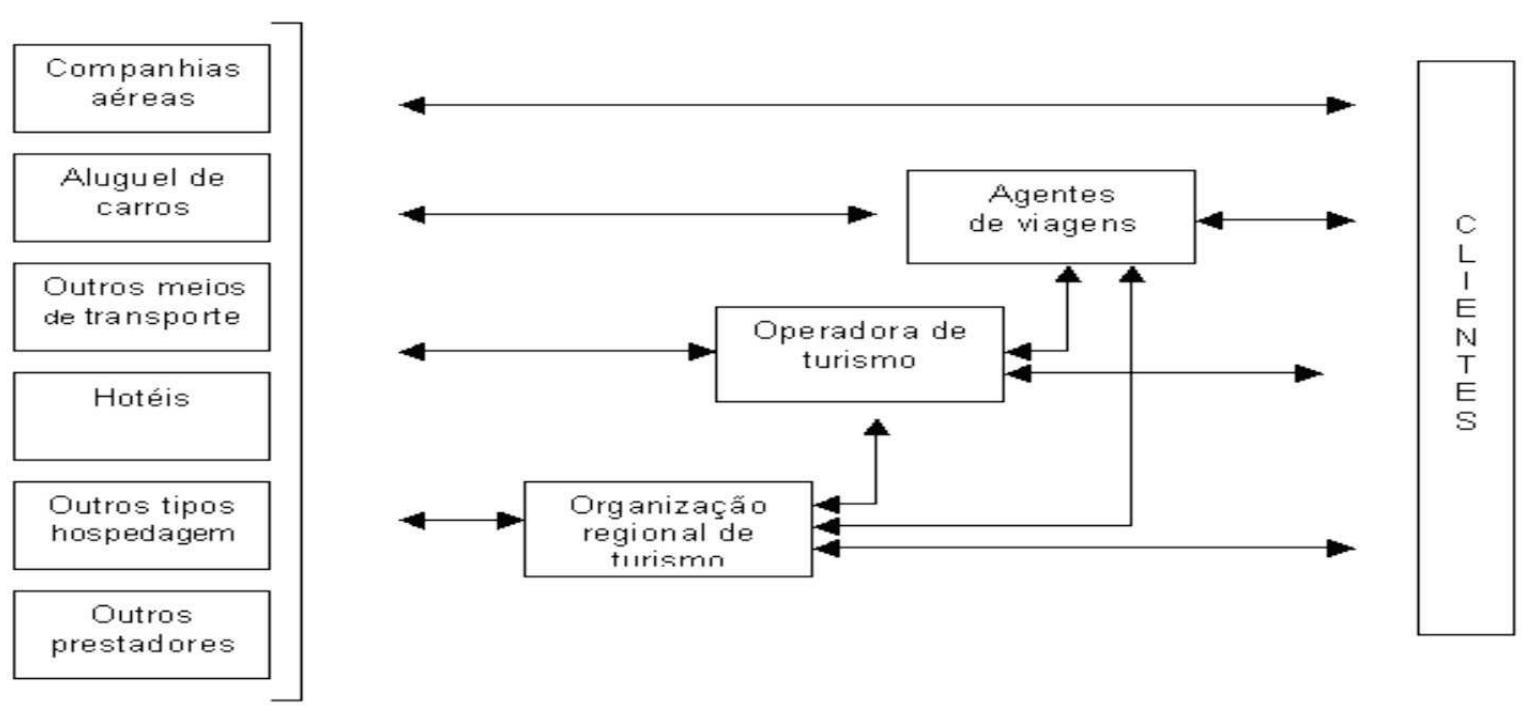

Figura 2: Canais de distribuição do turismo FONTE: O'CONNOR (2001)

Os principais produtores do setor turístico são, conforme a figura 2, as companhias aéreas, hotéis e empresas de aluguel de veículos, como também outros meios de transportes como o ônibus, outros meios de hospedagem, as pousadas e outros serviços do turismo.

\subsubsection{Pessoas}

A variável "pessoas" envolve o nível de serviço ao consumidor, políticas de recrutamento e treinamento, retenção e motivação de pessoal, entre outros. 
Pessoas referem-se a colaboradores e, às vezes, a clientes envolvidos na produção do serviço. COOPER et al. (2001), estabeleceu a seguinte divisão:

- Pessoas: Treinamento, critérios, comprometimento, incentivos, aparência, comportamento interpessoal e atitudes

- Outros clientes: comportamento, grau de envolvimento e contato cliente/cliente.

Os colaboradores tem que acreditar e confiar na organização na qual trabalham, nas pessoas e nos produtos e serviços. Políticas de benefícios e recompensas que as empresas oferecem aos funcionários, tais como, treinamentos, promoções, comissões, prêmios, planos assistenciais, convênios com outras empresas etc. são importantes para a motivação dos mesmos.

Na mesma linha, Albrecht (2000, p. 29) afirmou:

Cada funcionário de serviço é um administrador de certo modo. Cada um deles controla o resultado da hora da verdade exercendo controle sobre seu próprio comportamento em relação ao cliente. Se o pessoal de serviço for apático, desagradável, inamistoso, frio, distante ou pouco cooperativo, suas horas da verdade estarão indo "para o brejo" velozmente. Se for ativo, agradável, caloroso, amistoso, cooperativo e usar de iniciativa para resolver o problema do cliente, então suas horas da verdade serão brilhante, e o cliente tendera a generalizar essas experiências criando uma boa imagem feral de serviço.

O autor ainda inferiu que o treinamento de pessoal de serviço é apenas parte do processo de comunicação que se deve existir numa organização para que a mensagem seja transmitida com sucesso. Fazem-se necessários a cooperação e o entrosamento do trabalho em equipe para a boa qualidade nos serviços.

Assim como os clientes externos (hóspedes), os clientes internos (funcionários) e ao mesmo tempo colegas, devem ser cultuados e considerados como a extensão de qualquer negócio. Conforme Albrecht (2000), você pode nunca ver um cliente externo, mas isso não significa que as pessoas que apelem a você como clientes internos não precisem ter as suas necessidades atendidas por você da mesma maneira eficaz que é usada por uma pessoa de contato direto com os clientes externos.

As pessoas são tidas hoje como o recurso mais importante das empresas. São elas que de fato fazem o processo produtivo acontecer. Dessa forma, é preciso ter uma atenção especial para com estas pessoas, percebendo suas qualidades, defeitos, habilidades, aspirações 


\subsubsection{Processo}

O processo refere-se ao método particular de operações ou série de ações, normalmente realizadas pela empresa como, por exemplo, a responsabilidade social.

A Responsabilidade Social busca estimular o desenvolvimento do cidadão e fomentar a cidadania individual e coletiva. Sua ética social é centrada no dever cívico (...). As ações de Responsabilidade Social são extensivas a todos os que participam da vida em sociedade - indivíduos, governo, empresas, grupos sociais, movimentos sociais, igreja, partidos políticos e outras instituições (MELO NETO e FROES, 2001, p.26-27).

O papel da empresa começou a ser repensado na sociedade e o papel social surgiu como um espaço institucional e um novo campo de oportunidades para as organizações. Essas transformações, associadas às mudanças culturais, fizeram com que a sociedade despertasse também para uma consciência ambiental, situando o meio ambiente como um dos princípios fundamentais do consumidor moderno.

A atividade turística, no contexto do desenvolvimento sustentável, está inserida em diversos aspectos: econômicos, sociais, culturais, ecológicos e políticos, sendo que a oferta turística deve ser constituída por diversos componentes. As atrações construídas com propósitos específicos como: a rede de serviços (hotéis, gastronomia etc), sistemas de transportes, atividades de entretenimentos, contribuem para a experiência do turista tanto positiva quanto negativamente.

Segundo Giacomini Filho (2000), a empresa turística, entre outras, ao atuar no mercado, adota funções sociais diretas, conforme seus produtos, serviços e ações refletem diretamente na sociedade.

O Turismo, enquanto indústria centra-se nas relações econômicas, ligadas, primordialmente, às empresas turísticas. Então, analisar o turismo, enquanto fenômeno social consiste em reconhecer sua complexidade, as práticas sociais envolvidas, os impactos causados, o valor humano presente e suas diferentes formas de desenvolvimento (BURNS, 2002).

Segundo Dencker (2004), do ponto de vista da definição estratégica de marketing, a responsabilidade social pode ser vista como uma atitude gerencial para a obtenção de uma visão mais ampla ou percepção mais complexa do ambiente de negócios de uma organização. Ainda: "A responsabilidade social é uma parte 
importante do ambiente de marketing que influencia a forma como as empresa constroem e fortalecem os relacionamentos com os grupos de interesse".

\subsubsection{Promoção}

Segundo Kotler e Armstrong (1999), promoção consiste na combinação de propaganda, promoção de vendas, relações públicas e venda pessoal, para que a organização atinja os objetivos de marketing definidos. Como o objetivo de estudo deste trabalho são as ações de comunicação, será abordado separadamente o tópico comunicação de marketing.

\subsection{COMUNICAÇÃO DE MARKETING}

O composto de promoção é também o conjunto das decisões referentes à comunicação do hotel. Há basicamente duas decisões no processo de comunicação de marketing: quanto investir em promoção e como distribuir recursos entre as principais ferramentas de promoção disponíveis. Entende-se por composto promocional no turismo:

O programa total de comunicação de marketing de uma empresa, que consiste na combinação específica de propaganda, promoção de vendas, relações públicas e venda pessoal utilizados para atingir os objetivos de propaganda e marketing. (KOTLER e ARMSTRONG, 1995, p. 318 apud MOTA, 2001, p. 138).

Cooper et al. (2001), sintetizou como os objetivos promocionais podem ser desenvolvidos através da Figura 3. 


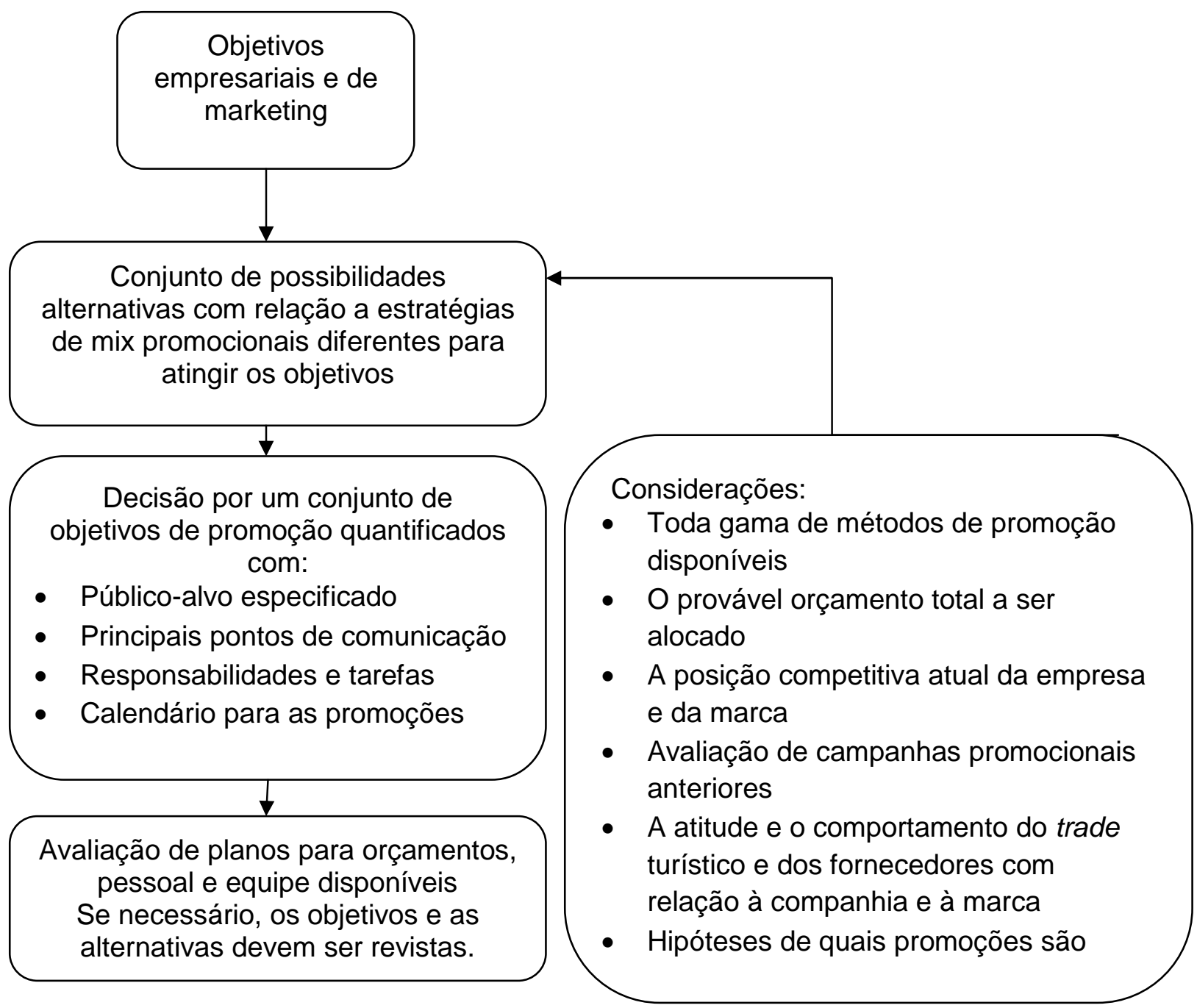

Figura 3: Desenvolvimento de objetivos promocionais FONTE: COOPER et al. (2001, p. 439)

Para Ruschmann (1999), a comunicação, uma vez dirigida a uma demanda mais específica, tem por objetivo principal atingir um publico diversificado, com diferentes necessidades de consumo (expectativas), pois a comunicação eficiente é aquela em que o emissor da mensagem detecta os desejos e anseios do publico alvo.

Segundo Lovelock (2005), em uma situação de serviço, como os hotéis (turismo), as ferramentas de comunicações de marketing são particularmente importantes porque, quando sabiamente utilizadas, podem criar imagens fortes e um senso de credibilidade, confiança e tranqüilidade. Mediante o uso de marcas nominais, elementos de design empresariais facilmente reconhecíveis e cenários de 
serviço bem montados, as empresas podem dar visibilidade e personalidade a suas intangíveis ofertas de serviço.

De acordo com Las Casas (2005), são várias as ferramentas para realização das promoções, como: propaganda, publicidade, relações públicas, venda direta e promoção de vendas.

\subsubsection{Propaganda}

A propaganda é qualquer forma paga de apresentação não-pessoal e promoção de idéias, bens ou serviços. As mídias de propaganda podem ser eletrônicas (televisão, sites, rádio, telemarketing) ou impressas (guias de viagens, jornais, revistas técnicas, outdoor, catálogos, mala-direta, etc.).

Kotler e Armstrong (1999) afirmaram que o telemarketing, o uso do telefone para vender diretamente aos consumidores, tornou-se uma ferramenta de comunicação importante do marketing direto. Em telemarketing ativo, os elementos para o sucesso são os objetivos, oferta, roteiro e habilidade em ouvir. $O$ telemarketing receptivo, entretanto, não significa apenas ouvir o cliente que está ligando. Significa uma oportunidade de vender e conquistar um cliente a partir de um interesse.

Catálogos e malas diretas correspondem ao envio de cartas, anúncios, amostras ou encartes para clientes de uma lista de correspondência (mailing list). A mala-direta é uma mídia muito utilizada, porém vender por correio não é comum. Ela é aplicada como uma ferramenta de apoio às vendas, sendo útil para explicar benefícios do produto, reforçar pontos de venda e manter clientes potenciais sempre informados sobre a empresa turística.

A Internet está se transformando num canal de vendas bastante eficiente para alguns segmentos de mercado, principalmente o consumo. No mercado hoteleiro, a Internet oferece vantagens competitivas, tais como: oferta de serviços e produtos e disponibilização de informações 24 horas por dia, com possibilidade de comparar preços e ofertas e atendimento ao cliente em tempo real (fazendo reservas on-line), dentre outras.

Já, os jornais e revistas "são notórios e reconhecidos formadores da opinião pública e têm uma interdependência com a democracia e com a livre iniciativa" (FORTES, 2003, p. 220). Já Andrade, (1993, p. 120) corrobora tal 
afirmação, destacando que "as revistas, ao contrário dos jornais, não são lidas apressadamente e geralmente são conservadas por muito tempo. Além disso, podem oferecer melhor apresentação [...]".

\subsubsection{Publicidade}

A publicidade é fundamental para atingir os objetivos de fazer chegar as mensagens aos clientes potenciais. Veira (2003, p. 141), afirmou que uma das formas de publicidade é a gratuita e "a hotelaria é um dos poucos segmentos que têm o privilégio de poder obter publicidade gratuita com certa facilidade”. A publicidade gratuita é qualquer apresentação impessoal; por notícias comercialmente significantes, por meio publicado, ou pela obtenção de uma apresentação favorável na mídia.

A publicidade ajuda a promover a empresa de forma mais crível do que a propaganda paga. Uma das formas de publicidade mais utilizada é o boca a boca. Conforme Pires (2003, p. 44):

A importância da comunicação boca-a-boca como instrumento de promoção da empresa não deve se limitar a sua ocorrência como conseqüência dos esforços de outras ferramentas do composto de comunicação, mas ser visto como um instrumento que pode ter vida própria e, por isso, com enorme potencial de proporcionar acréscimos de vendas, conquistando clientes que serão conduzidos a se tornarem os próximos divulgadores da empresa, à semelhança daqueles que os incentivaram a fazer a primeira compra.

E ainda segundo Hoffman e Bateson (2003 apud Sergio, 2006), uma das

diretrizes para o desenvolvimento das comunicações em serviços é desenvolver uma rede de comunicações boca a boca. Clientes de serviços muitas vezes dependem mais de fontes pessoais de informações do que de fontes impessoais para reduzir o risco de uma compra. Dada a importância das fontes pessoais, devem ser desenvolvidas comunicações que facilitem sua disseminação.

Já Little (2005, p. 63), nomeou o famoso marketing boca-a-boca de marketing viral.

Por tratar de uma estratégia que encoraja indivíduos da sociedade a repassar uma mensagem de marketing para outros, criando potencial para o crescimento exponencial tanto na exposição como na influencia da mensagem. Como os vírus reais, tais estratégias aproveitam o fenômeno da rápida multiplicação para levar uma mensagem a milhares e ate milhões de pessoas.

O marketing boca a boca ou viral é uma das formas mais fácil fáceis de divulgação, pois as pessoas quando tomam conhecimento de determinado produto 
ou serviço através de uma segunda pessoa, há uma maior confiança, pois alguém, próximo a ele já o experimentou. Merece, também, todo o cuidado nesta forma de divulgação, pois um cliente não satisfeito poderá promover com maior veemência uma imagem negativa do produto do que um cliente satisfeito

\subsubsection{Relações Públicas}

O termo relações públicas consiste na comunicação com os vários públicos da organização, pela obtenção de publicidade favorável, construção de uma boa imagem corporativa e pela manipulação de histórias ou eventos desfavoráveis à empresa.

Hooley et al. (2006, p. 288) afirmou:

Muitas empresas hoje fazem um péssimo uso de potencial das relações publicas, essencialmente, consistem na criação de relacionamentos com a mídia e no uso desses relacionamentos para ganhar uma exposição positiva. Press releases e entrevistas com os principais executivos sobre tópicos importantes podem ajudar a promover a empresa de maneira mais confiável do que a propaganda tradicional.

O desenvolvimento de relações públicas $(\mathrm{RP})$ pode abranger a utilização de SAC (Serviço de atendimento ao consumidor), Ombudsman (profissional que representa a empresa), patrocínio de eventos ou serviços de 0800 e visitas para conhecer a empresa, por exemplo. As visitas, segundo Andrade (1993, p. 140), possuem "grande vantagem nesse contato pessoal direto que se estabelece entre a organização e os seus públicos”.

Para Siqueira (1992, p. 294), os meios de atuação de um profissional de RP podem ser divididos nos níveis:

- Nível indireto: Relações com a imprensa, propaganda institucional, propaganda na mídia, promoção de vendas.

- Nível direto: Treinamento de comunicação e relacionamentos com o público (para funcionários que mantêm contatos com clientes), palestras e conferências, criação de cartas, relatórios, etc., serviço de atendimento aos clientes.

Da mesma forma relatou Costa (2009):

Com base em uma visão estratégica, podemos dizer que as Relações Públicas, na hotelaria, devem assumir o papel de condutora do trabalho de Comunicação da empresa. Para o público interno, elas poderão ser encarregadas de proporcionar, em parceria com a área de Recursos Humanos, as condições necessárias para o bom relacionamento e para a satisfação no tocante ao serviço. Isto é uma das condições básicas 
para o hóspede ter prazer ao utilizar o hotel. Referente ao público externo, as Relações Públicas deverão trabalhar para a promoção de um canal permanente de comunicação entre o hotel e seu consumidor final: o hóspede. É em função dele que uma empresa hoteleira deve pensar e agir. Esse canal pode ser estruturado de diversas formas: através de uma política de divulgação institucional, pesquisas de opinião, estudo de mercado, programas especiais para hóspedes freqüentes, entre outras.

Pode-se dizer que as organizações que desejam estabelecer uma comunicação adequada, eficaz e excelente, através de planejamentos e relacionamentos, necessitam estruturar-se corretamente, identificando seus pontos fortes e fracos. Para tanto, é fundamental a atuação do profissional de Relações Públicas no conhecimento e na análise dos componentes nos cenários estratégicos organizacionais, com a finalidade de conciliar os diferentes interesses.

\subsubsection{Vendas Diretas}

É a apresentação pessoal da força de vendas da empresa, com o propósito de realizar vendas e criar relações com os clientes. A vantagem desse tipo de comunicação é que o vendedor consegue perceber a necessidade do cliente, e adapta os benefícios dos serviços vendidos às necessidades. No marketing a venda porta a porta ou pessoal é a ferramenta de promoção mais importante, ou como diz Las Casas (2005, p. 250), que a "venda direta é uma das mais eficientes ferramentas de comunicação".

Há uma série de instrumentos de venda que o vendedor pode utilizar para facilitar o processo de venda. Siqueira (1992) apresentou quatorze itens, dentre os quais se podem citar: benefícios ao cliente, qualidade do produto, desvantagens da concorrência, prestígio da empresa, serviços de pós venda, contatos pessoais, perguntas específicas, dentre outros.

Para Cooper et al. (2001), a intenção das vendas diretas é:

- Obter uma venda: muitas vezes os clientes entram na loja depois de adquirir informações e o vendedor tem que persuadir clientes em potencial e fazer uma aquisição

- Estimular as vendas "por impulso", trazendo atenção para necessidades extras, como seguros de viagens, aluguel de carros, excursões e traslados de aeroportos 
- Complementar uma transação bem-sucedida com o cliente, utilizando uma série de habilidades de venda. Isto deixará o cliente satisfeito e bem informado sobre os detalhes da transação.

\subsubsection{Promoção de Vendas}

Promoções de vendas são atividades de marketing como exibições, demonstrações, espetáculos, feiras comerciais, convenções, amostras, dentre outros. Podem ser definidas também como incentivos de curto prazo para gerar compra ou venda de produtos e/ ou serviços.

$\mathrm{Na}$ hotelaria, a promoção de vendas caracteriza-se principalmente pela montagem de showroom ou de estandes em feiras. As feiras e exposições são grandes oportunidades para promover produtos e serviços. Além dessas atividades, de acordo com Las Casas (2005) ainda existem: amostras (no caso de hotéis poderiam ser cortesias de diárias de hospedagem), prêmios e vales brindes, cupons, concurso e jogos.

De acordo com Vavra (1993) produtos com a marca da empresa devem ser dados como brinde e realçam o sentimento de identificação. A confecção de brindes devidamente personalizados tem servido para divulgar a empresa (hotel). 


\section{A PESQUISA}

O Hotel em estudo pertence a uma rede hoteleira internacional, que está em operação há mais de dez anos, e tem como objetivo criar hotéis que atendam clientes em viagens de negócios e lazer, seguindo a filosofia de satisfazê-los com serviços e produtos de qualidade, a preços justos. Possui diversas bandeiras, podendo proporcionar um atendimento diferenciado para hóspedes acostumados com hotéis de três a cinco estrelas, com foco no público executivo regional e internacional.

Neste trabalho, o hotel pesquisado foi denominado de Hotel $X$, por solicitação da preservação do nome pelos gestores. Cabe ressaltar que o tratamento dos dados foi feito de forma a garantir essa confidencialidade das informações obtidas. Em nenhum momento é divulgado o nome da Rede e do Hotel, bem como o nome dos entrevistados.

Segundo Yin (2005) existem três fundamentos que justificam o anonimato de um estudo de caso. São eles:

a) Proteção do caso real e seus participantes;

b) A divulgação do relatório final pode interferir nas ações seguintes das pessoas envolvidas;

c) Pode retratar o chamado "tipo ideal".

O Hotel $X$ foi inaugurado há quatro anos e é voltado para o turismo de negócios, devido à cidade em que se localiza ser predominantemente marcada por esse tipo de turismo. É um hotel de categoria econômica, possui mais de 100 apartamentos, com cama box king size, TV a cabo e internet banda larga. Conta ainda com estacionamento, salas de eventos, fitness center, business center, piscina e restaurante terceirizado.

O Hotel difere de outros por pertencer a investidores que, com o intuito de participarem dos dividendos do negócio, adquiriram o apartamento que continua participando do pool hoteleiro. Pool Hoteleiro é um sistema associativo em que os proprietários de unidades destinam-nas para a exploração hoteleira. Constituem objeto desse sistema associativo, além dos apartamentos integrantes do hotel, as suas respectivas áreas e bens comuns, as salas de convenções, incluindo todo o seu mobiliário, equipamentos, utensílios, instalações, e decoração. Mesmo que a 
unidade comprada não seja utilizada, o investidor receberá sobre o rendimento do hotel (Soluções Informática, 2009).

Em relação ao desempenho do Hotel, nota-se que ele vem conquistando mercado progressivamente. Mesmo que em 2008 tenha contado com a menor ocupação (OCP) da cidade, a diária média é trabalhada com esmero, ficando quase 30\% acima do mercado, conforme Quadro 6. Grande parte desse resultado deve-se aos eventos locais e regionais, como festa agropecuária, feiras industriais e turismo religioso.

Quadro 6. Ocupação e diária média do ano de 2008

\begin{tabular}{|c|c|c|}
\hline \multicolumn{2}{|c|}{ DADOS REFERENTES AO ANO DE 2008 } \\
\hline EMPREENDIMENTOS & DIARIA MÉDIA & OCUPAÇÃO \\
\hline HOTEL X & $\mathrm{R} \$ 97,10$ & $43,80 \%$ \\
\hline CONCORRENTE 1 & $\mathrm{R} \$ 72,25$ & $45,00 \%$ \\
\hline CONCORRENTE 2 & $\mathrm{R} \$ 74,63$ & $46,25 \%$ \\
\hline CONCORRENTE 3 & $\mathrm{R} \$ 60,13$ & $49,75 \%$ \\
\hline
\end{tabular}

Visando aumentar a ocupação média do Hotel X, foi elaborado um projeto de marketing, para o ano de 2009, onde se delineou um plano de trabalho objetivando não apenas o planejamento de marketing ofertado pela rede como também um planejamento sugestivo a ele em especial.

\subsection{MÉTODOS DE PESQUISA}

O trabalho está limitado à análise de um hotel de rede internacional no interior do estado de São Paulo. Esta escolha consagrou-se pelo Hotel X pertencer a uma rede hoteleira internacional e ter a veiculação de propaganda não só na cidade local, mas em todo país, por possuir hotéis em quase todos os estados brasileiros.

Para realização da pesquisa foi necessário, primeiramente, conhecer efetivamente as estratégias utilizadas pelo Hotel para efetivação de ações de comunicação, por meio de uma pesquisa qualitativa. De acordo com Richardson (1999), a pesquisa qualitativa é o método de estudo que tenta compreender detalhadamente os significados e características situacionais, podendo ser do tipo descritiva. Afirma o autor, que este método é utilizado quando se deseja entender detalhadamente o porquê um indivíduo pratica determinada decisão. Ou seja, a 
pesquisa qualitativa envolve a obtenção de dados descritivos resultantes do contato direto do pesquisador com a situação estudada.

Assim como Cervo e Bervian (1996, p.49) afirma que "a pesquisa descritiva observa, registra, analisa e correlaciona fatos ou fenômenos (variáveis) sem manipulá-los”.

Entre as várias formas que a pesquisa qualitativa pode assumir, têm-se os estudos de caso, método que também foi aplicado nesta monografia. Para Gil (2002, p. 58) o estudo de caso, "é caracterizado pelo estudo profundo e exaustivo de um ou de poucos objetivos, de maneira que permita o seu amplo e detalhado conhecimento".

A decisão de adotar esse tipo de pesquisa qualitativa deu-se por algumas de suas características como: visar à descoberta; enfatizar a interpretação do contexto em estudo, buscar retratar a realidade de forma completa e usar várias fontes de informação.

Juntamente com a pesquisa qualitativa foi elaborada uma pesquisa de campo. Fachin (2001, p.133) afirma que:

A pesquisa de campo se detém na observação do contexto no qual é detectado um fato social (problema), que a principio passa a ser examinado e, posteriormente, é encaminhado para explicações por meio dos métodos e das técnicas específicas.

A pesquisa bibliográfica foi desenvolvida no decorrer do trabalho, com algumas teorias analisadas como as de Kotler (1993, 1999, 1998 e 2000), Las Casas (2005), Cooper et al. (2001), Cobra (2001), Gronroos (1995) entre outras, enfatizando conceitos sobre plano de marketing, turismo, hotelaria, marketing de serviços, turísticos e relacionamento, marketing estratégico e tático, segmentação de mercado, marketing mix e ações de comunicações de marketing.

Os instrumentos da pesquisa aproveitados foram os seguintes:

- Entrevistas informais por telefone com gestor e funcionários do hotel;

- Estudos de dados primários, que conforme Malhotra (2001) são aqueles originados pelo pesquisador com o objetivo específico de abordar o problema em estudo;

- Estudo de dados secundários, que foram coletados para outros objetivos que não os do problema em questão, mas que puderam auxiliar na pesquisa;

- Análise e interpretação dos dados e avaliação de resultados. 
Para realização desta monografia os métodos utilizados incluíram: comunicação pessoal, por telefone, pela internet, métodos de observação, fontes públicas e privadas de informações, e análise de dados fornecidos pelo hotel em estudo.

\subsection{LIMITAÇÕES DA PESQUISA}

A presente pesquisa teve como objetivo analisar as ações de comunicações do Hotel X. Mas alguns fatores limitaram este estudo, como:

- Por estar atravessando alguns problemas operacionais o Hotel X, não autorizou a realização de entrevistas e a aplicação de questionários até a data prevista e necessária para a tabulação dos dados.

- A pesquisa de campo apenas foi feita por meio de conversas informais, e dados oferecidos pelo hotel, sem considerar a percepção dos hóspedes em relação às ações de comunicação e marketing do hotel.

- A pesquisa não responde no total ao tema do trabalho, sendo que quando são oferecidos dados de veículos de comunicação (como os clientes "descobriram" o hotel), não são fornecidas as ações específicas. Ex: Revistas: quais seriam estas revistas? 


\section{DESCRIÇÃO E ANÁLISE DE DADOS}

\subsection{DESCRIÇÃO DE DADOS}

De acordo com Las Casas (2005) a definição do público alvo que o Hotel pretende atingir é muito importante para conhecer as ações de comunicação que deverão ser realizadas, por isso tem a preocupação em saber quem são os hóspedes, sua procedência e a razão de sua viagem, se é a lazer, a negócio ou com finalidade religiosa etc.

Através do Quadro 7 foram mensurados os segmentos trabalhados pelo Hotel X: individual, empresas, FAVECC'S ${ }^{1}$, agência de viagem nacional e internacional, operadoras ${ }^{2}$ nacional e internacional, feiras e congressos $e$ investidores.

Quadro 7. Estatísticas de pernoites por segmentos de mercado em um Hotel do interior de São Paulo, no período de 60 dias no ano de 2009.

\begin{tabular}{|c|c|}
\hline SEGMENTO - ORIGEM RESERVAS & PERNOITE EM 60 DIAS \\
\hline Empresas & 905 \\
\hline Feiras e congressos & 0 \\
\hline Individual & 659 \\
\hline FAVECC & 463 \\
\hline Agência nacional & 184 \\
\hline Agência internacional & 12 \\
\hline Operadora nacional & 156 \\
\hline Operadora internacional & 4 \\
\hline Cortesia & 15 \\
\hline Uso da casa & 0 \\
\hline Investidor & 0 \\
\hline Outros & 0 \\
\hline
\end{tabular}

\footnotetext{
${ }^{1}$ FAVECC - Fórum das Agências de Viagens Especializadas em Contas Comerciais - é uma entidade focada em viagens de negócios e no gerenciamento de contas de viagens corporativas, tendo como um de seus principais objetivos servir aos seus associados, clientes e parceiros, como referência nacional nesse segmento (FAVECC, 2009)

2 Segundo Pellegrini Filho $(2000$, p. 187) é a empresa responsável pela organização do pacote turístico, ou seja, a que contrata os prestadores de serviços turísticos, tais como: transportes, hospedagem, traslados, passeios, alimentação e etc. Esses pacotes são repassados as agências de viagens, que se encarregam da comercialização e são, considerados como principais canais de distribuição dos produtos turísticos.
} 
Além da origem das reservas, é importante saber qual a procedência dos hóspedes, principalmente para o acionamento das equipes de vendas, veremos a importância dessa ação no decorrer do trabalho. O quadro 8 demonstra a relação de pernoites por estado brasileiro de procedência dos clientes.

Quadro 8. Estatísticas de pernoites por Estado de procedência do hóspede em um Hotel do interior de São Paulo, no período de 60 dias no ano de 2009.

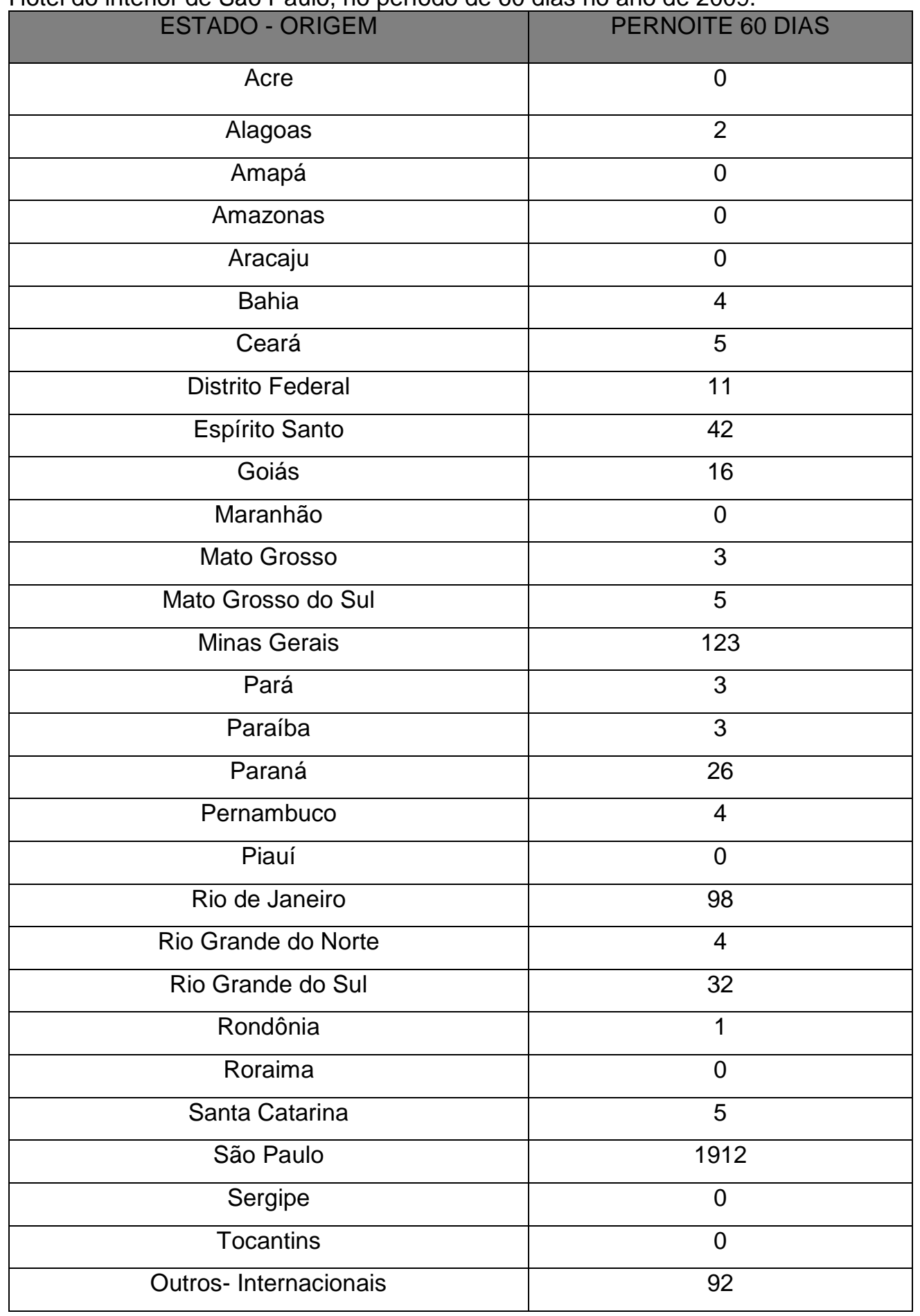


O mercado que o Hotel pretende atingir, deverá ser visitado constantemente; pela equipe de vendas, principalmente o do estado de São Paulo, onde é o maior pólo emissor de reservas como foi verificado na tabela acima. $O$ Hotel $X$ ainda tem à sua disposição, a relação detalhada de produção de pernoites de cada segmento originário de reservas com seus devidos nomes, por exemplo: Segmento Agência de Viagens - Agência Vida Bela. Isso facilita ainda mais o trabalho com as ações de comunicação de venda direta e entrega de brindes.

Com essa relação, ainda é possível verificar em quais empresas são feitas ações de comunicação e não tem havido êxito. Às vezes, por exemplo, a equipe de vendas visita determinada empresa, levando brindes e cortesias, sendo que a mesma não apresentou a produção esperada. A partir daqui, surgem algumas indagações: as ações não estão sendo eficientes? Ou o hotel não está satisfatório? Ou o problema é preço?

O segmento de empresas é o de maior produção de pernoites, fazendo uma contradição com os investidores. Vale ressaltar esse dado interessante, apresentado no Quadro 7, onde os investidores num período de sessenta pernoites não tiveram uma hospedagem. Isso acontece, pois o Hotel X, mesmo já posicionado no mercado local como o melhor hotel do município, ainda não conseguiu atender aos anseios dos investidores, que é a distribuição dos lucros. A participação em reuniões por parte destes ainda é pequena e também, por mais de $50 \%$ dos apartamentos pertencerem a um único investidor. Embora tendo conhecimento do mercado local e a crise econômica que a cidade vem sofrendo, há uma grande insatisfação por parte dos investidores devido à falta da participação nos lucros do hotel, como dito anteriormente, o que não os motiva a investir plenamente no hotel.

Os objetivos e expectativas dos investidores são definidos como o retorno do investimento e posicionamento do produto no mercado, com excelente ocupação e atendimento. E, como a previsão da demanda para 2009 será de permanecer a mesma de 2008 a estratégia a ser adotada será a do gerenciamento da diária. Pretende-se assim manter os clientes com negociações pontuais e recorrer a tarifas mais elevadas nas vendas para FAVECCS, operadoras e clientes diretos, mesmo que contrarie a expectativa do consumidor final que presume a oferta de diária mais acessível comparada com a hotelaria local.

As reservas individuais são originadas por eventos como casamentos, formaturas, finais de semana, walk ins entre outros. A maioria das reservas 
individuais é proveniente da ação de indicação, que é atualmente uma das ações de comunicação que traz maior índice de ocupação ao Hotel X, conforme poderá ser notado na próxima tabela.

Além do conhecimento do público alvo, deve-se ter pleno conhecimento dos produtos e serviços prestados aos clientes, de forma a analisar os principais atributos destes que os consumidores valorizam.

Os hóspedes e clientes, ao se decidirem por uma empresa esperam receber um excelente atendimento aliado a um produto que lhes ofereça qualidade $e$ satisfação. E para isso, o Hotel $X$, segue os padrões e procedimentos hoteleiros internacionais mantendo e investindo fortemente no atendimento e treinamento de pessoal para a excelência e superação da expectativa dos hóspedes.

Vale ressaltar ainda os pontos fortes e fracos do Hotel. Pontos que atraem muitos hóspedes é ser um empreendimento novo e possuir um restaurante de excelente qualidade ganhando mercado dos concorrentes. Podem ser considerados ainda pontos fortes, o atendimento, segurança através de câmeras, vigias 24 horas e os programas de fidelização. No entanto a localização do referido hotel torna-se ao mesmo tempo um ponto forte e fraco, isto porque, alguns dos hóspedes preferem-no pela proximidade á rodovia e a distância do centro da cidade, já outros, no entanto, não gostam pelos mesmos motivos. Destacam-se outros pontos fracos do Hotel $X$ como a área limitada do restaurante em relação à capacidade das salas de eventos, a falta de secador de cabelos no apartamento e o estacionamento sem cobertura.

Obtendo o conhecimento do segmento a ser atingido e dos serviços do hotel, procede-se para a análise das ações de comunicação. Como o Hotel X pertence a uma rede hoteleira, foram analisadas as necessidades individuais de cada hotel e o cruzamento de interesses comuns dos grupos de hotéis. Foram, então, propostas ações em três diferentes níveis: coletivas, cooperadas e exclusivas.

As ações coletivas são as atividades promocionais em benefício de toda a rede, sempre com destaque em todos os hotéis e suportada por verba estipulada da previsão orçamentária anual de cada empreendimento. Um dos principais objetivos dessas ações é dar continuidade á campanha do ano anterior tendo em vista o sucesso comprovado desse tipo de esforço.

Essas ações de comunicação de marketing realizadas, a partir da arrecadação de parte da receita de hospedagem de cada um dos hotéis, permitem 
aos empreendimentos da rede participarem de ações promocionais de alto impacto e ampla cobertura, impossíveis de serem realizadas de forma individualizada.

Alguns exemplos de ações coletivas são:

- Propagandas em revistas de empresas de aviações,

- Divulgação em jornal de circulação entre agentes de viagens e outros profissionais do turismo,

- Banner na internet em jornais de repercussões nacionais.

Essas ações, em sua maioria, são consideradas para incentivos da marca. Seria uma forma do cliente estar efetivamente lembrando-se do logotipo, marca etc.

As ações cooperadas consistem nas atividades promocionais em benefício de um grupo de dois ou mais hotéis da rede, que rateiam os custos para sua realização. Elas podem ser praticadas em agências, empresas, grupos e eventos e usuários diretos. Entre as ações cooperadas de comunicação pode-se citar:

- Ações em empresas de forma a atingir os responsáveis pelas reservas de hotéis;

- Visitas para entregas de brindes tanto em empresas quanto em grupos e eventos;

- Confecção de malas diretas abordando as necessidades das empresas (ex: conforto, sala de reunião, e lazer),

- Ações com grupos e eventos possuem, em sua maioria, o objetivo deles conhecerem o hotel e a sua estrutura, principalmente da parte de eventos,

- Pôsteres nos elevadores dos hotéis: criação e impressão de pôster para exposição nos hotéis divulgando outros da rede,

- E-mail marketing: divulgação de um hotel ou um grupo deles com promoções.

Para atender as necessidades específicas de cada hotel têm as ações exclusivas, que se referem às atividades promovidas de forma individualizada de acordo com a estratégia de marketing traçada e financiada exclusivamente através de sua verba própria.

As ações de comunicação do Hotel X são:

- Confecção de painel para instalação na principal rodovia de acesso à cidade, para divulgação do Hotel. Esta ação foi planejada, após ter sido estudado a 
concorrência da região, onde foi detectado que os hóspedes sem reservas (walk-ins) levavam em consideração esse tipo de propaganda, por muitas vezes não conhecerem a cidade, e nessa mesma rodovia há painéis dos principais concorrentes;

- Banner localizado na frente do hotel com tarifa promocional visando aumento da diária média e ocupação através dos walk-ins;

- Utilização de placas de sinalização em pontos estratégicos da cidade, mencionando como chegar ao Hotel;

- Folheteria (Postais e Folders) distribuídos nos hotéis da rede, agências de viagens e turismo, empresas, comissões de formaturas e promotores de eventos;

- Mala direta para noivos da lista de casamento que é fornecida pelos cartórios locais com o objetivo principal de melhorar a ocupação nos finais de semana;

- Participação em eventos culturais, de negócios e esportivos para divulgação da marca e incremento da diária média aproveitando os períodos de feiras e congressos com alta demanda na cidade.

Para melhor trabalhar o segmento de agências e operadoras de viagem, foi requerido auxílio de uma equipe de vendas (faz parte de uma empresa coligada à rede, conforme veremos com detalhes no decorrer da pesquisa). Essa equipe atua em todo o Brasil, utilizando como estratégias as visitas às operadoras, agências e FAVECCS e desta forma realizando, também, um gerenciamento de canais de distribuição. Para o segmento de empresas são realizadas visitas objetivando o aprimoramento do relacionamento com as empresas locais, evidenciando ainda, a convivência com as equipes de vendas de outras regiões a fim de orientá-los em relação ao mercado local.

O Hotel X para mensurar a eficiência dessas ações de marketing, elabora um relatório com as estatísticas das ações de comunicação. O hóspede ao efetuar o check-in no hotel é interrogado em qual circunstância conheceu o hotel. No quadro 9 seguem os dados da indagação: 
Quadro 9. Estatísticas de pernoites em relação ao veículo de comunicação que motivou-a, em um Hotel do interior de São Paulo, no período de 60 dias no ano de 2009.

\begin{tabular}{|c|c|}
\hline AÇÕES DE COMUNICAÇÃO & PERNOITES EM 60 DIAS \\
\hline Visita de equipe de vendas & $1278^{3}$ \\
\hline Indicação & 664 \\
\hline${\text { GDS (Global Distribuition System) }{ }^{4}}^{\text {Luminoso }}$ & 189 \\
\hline Agentes de viagens & 110 \\
\hline Empresa & 36 \\
\hline Email & 32 \\
\hline Internet & 27 \\
\hline Site da rede & 23 \\
\hline Guias/Paginas amarelas & 11 \\
\hline Outdoor & 6 \\
\hline Telemarketing & 17 \\
\hline Folheteria & 0 \\
\hline Mala direta & 2 \\
\hline Outros & 3 \\
\hline
\end{tabular}

Através desses quadros 7, 8 e 9, respectivamente segmentos e ações de comunicação, o Hotel $X$ elabora planilhas para a efetivação de ações, conforme demonstrado no quadro 10:

\footnotetext{
${ }^{3}$ Os dados referentes à visita de equipe de vendas, não se refere a visitas individuais e sim, por exemplo, funcionários de certa empresa que recebeu a visita da equipe de vendas.

${ }^{4}$ GDS: Conexão com mais de 500.000 terminais de agentes de viagens e 74 mercados. Ações: Incrementa receita e ocupação do hotel; agentes de viagens de todo mundo podem facilmente reservar seu hotel ou rede de hotéis; processamento de confirmação instantâneo; marketing direto do hotel a nível mundial e confirmação instantânea das reservas (Interlink, 2009).
} 
Quadro 10. Segmentos X Canais de Distribuição X Ações de Comunicação do Hotel X

\begin{tabular}{|c|c|}
\hline \multicolumn{2}{|c|}{ Individual (escolas, universidades, faculdades, buffet, casamento, associações comercias) } \\
\hline $\begin{array}{l}\text { Canais de Distribuição } \\
\text { (Origem de Reserva) }\end{array}$ & Ações de Comunicação \\
\hline Direto & $\begin{array}{c}\text { Visitas, telemarketing, email } \\
\text { Mala Direta, Participação em Feiras } \\
\text { (Feira de noivas, por exemplo), outdoor, } \\
\text { Anúncios em jornal local }\end{array}$ \\
\hline \multicolumn{2}{|r|}{ Empresa } \\
\hline $\begin{array}{l}\text { Canais de Distribuição } \\
\text { (Origem de Reserva) }\end{array}$ & Ações de Comunicação \\
\hline $\begin{array}{c}\text { FAVECC, Agência de Viagens, } \\
\text { Central de Reservas }\end{array}$ & Visitas, telemarketing, email \\
\hline Direto & $\begin{array}{l}\text { Indicação, visitas } \\
\text { telemarketing, email, outdoor na rodovia }\end{array}$ \\
\hline \multicolumn{2}{|c|}{ Agência de Viagem Nacional } \\
\hline $\begin{array}{l}\text { Canais de Distribuição } \\
\text { (Origem de Reserva) }\end{array}$ & Ações de Comunicação \\
\hline Cmnet (site de reservas on line) & Visitas, email \\
\hline Direto e Central de Reserva & Visitas, email, brindes \\
\hline \multicolumn{2}{|r|}{ FAVECC } \\
\hline $\begin{array}{l}\text { Canais de Distribuição } \\
\text { (Origem de Reserva) }\end{array}$ & Ações de Comunicação \\
\hline $\begin{array}{c}\text { Cmnet,Central de Reservas, } \\
\text { direto }\end{array}$ & Visitas, Telemarketing, brindes \\
\hline \multicolumn{2}{|c|}{ Operadora Nacional } \\
\hline $\begin{array}{l}\text { Canais de Distribuição } \\
\text { (Origem de Reserva) }\end{array}$ & Ações de Comunicação \\
\hline Central de Reserva e direto & Mala direta, telemarketing, email, brindes \\
\hline \multicolumn{2}{|c|}{ Feiras e Congressos } \\
\hline $\begin{array}{l}\text { Canais de Distribuição } \\
\text { (Origem de Reserva) }\end{array}$ & Ações de Comunicação \\
\hline $\begin{array}{l}\text { CMnet, direto e central de } \\
\text { reservas }\end{array}$ & Visitas, email marketing e telemarketing \\
\hline \multicolumn{2}{|r|}{ Investidor } \\
\hline $\begin{array}{l}\text { Canais de Distribuição } \\
\text { (Origem de Reserva) }\end{array}$ & Ações de Comunicação \\
\hline Direto & Visitas \\
\hline
\end{tabular}

Fonte: Plano de Ação e Vendas do Hotel X.

O quadro 10 é parte do Plano de Ação e Vendas anual do hotel. Há também a elaboração de planilhas mensais com as ações que serão executadas 
pelo departamento de vendas. A seguir, será apresentada a análise de dados de acordo com suas descrições.

\subsection{ANÁLISES DE DADOS}

A análise dos resultados da pesquisa foi proferida com base nos conceitos expostos na revisão bibliográfica deste estudo, abordando as ações de comunicação em um Hotel de Rede internacional. Com a impossibilidade da realização de questionários, foram analisados os dados fornecidos pelo Hotel juntamente com as entrevistas informais.

O trabalho de marketing tanto na Rede quanto no Hotel X é intensa, sendo determinante para as ações de comunicação. O marketing tem como preocupação o comprometimento das pessoas com a marca e com isso, a padronização dos hotéis e os tipos de parcerias que irão ser estabelecidas, ficam acoplados às ações de comunicação. A valorização da natureza, dos serviços, dos trabalhos de defesa com o meio ambiente, a valorização da parte de responsabilidade social também fazem parte do trabalho de marketing, como afirmado por Dencker (2004).

As principais ações de Marketing dentro da Rede são: acompanhar as tendências dos segmentos do mercado atuante, identificar oportunidades de negócios com os clientes e não-clientes em potenciais e manter, qualificar e atualizar - banco de dados. A participação e valorização das idéias apresentadas, principalmente a manutenção e a fidelização do cliente, são tão importantes quanto às decisões sobre campanhas promocionais para atender a valorização da marca, aprimorar os serviços, acompanhar investimentos e analisar resultados.

Em conformidade com o conceito de Las Casas (2005) de que o marketing é uma filosofia de trabalho que envolve tudo e todos de uma organização e que busca a captação e manutenção de clientes satisfeitos em uma relação mais duradoura possível, percebe-se que a Rede estrutura e desenvolve corretamente suas ações de marketing.

Para isso ocorrer, é necessário que a empresa evidencie seus atributos, divulgando uma marca e produtos/serviços fortes. A Rede tem vários produtos e serviços para oferecer, portanto, tem que ter ações de comunicação planejadas e voltadas para um determinado tipo de público. E, quanto maior for a clareza e a 
eficiência dessas ações, maior será a expectativa gerada pelo cliente, garantindo assim altos níveis de satisfação.

Vale ressaltar, que a Rede comunica-se bem tanto internamente quanto externamente. Isso se deve à eficácia dos instrumentos de comunicação utilizados pela equipe e pelo seu espírito de integração. A Rede utiliza adequadamente a comunicação interna, já que primeiro há uma preocupação com os colaboradores, pois quando esses não estão satisfeitos, não trabalham motivados e o cliente sente isso, principalmente na parte operacional, conforme afirmado por Oliveira (2001).

O principal objetivo desse tipo de comunicação é fazer com que os colaboradores comprometam-se com a empresa e com a imagem organizacional como se fosse sua própria imagem. Um bom trabalho interno contribui para que os funcionários sejam os primeiros informados de mudanças e notícias, conheçam todos os produtos e serviços da Rede e saibam divulgá-los.

A comunicação interna da Rede e do Hotel é composta por:

- Comunicados;

- Memorandos;

- Informativo eletrônico na Intranet com todos os fatos de interesse corporativo, como matérias publicadas na mídia;

- Murais localizados nas entradas de serviço dos colaboradores, nos refeitórios e nos setores de Recursos Humanos;

- Reuniões diárias para solução de problemas operacionais e análise das ações da equipe de vendas;

- Reuniões mensais do Conselho de Administração, formado por acionistas/investidores;

- Assembléia Geral Ordinária com acionistas realizada anualmente.

Cumpre ressaltar que a pertinência das reuniões foi enfocada como um diferencial nas estratégias comunicacionais.

A importância da comunicação interna para a divulgação do hotel é enorme, pois não adianta divulgar no site uma foto linda e perfeita do hotel e praticar uma ação de comunicação externa eficaz, se dentro do hotel não houver um tratamento adequado e não existir uma boa comunicação. 
Mas a eficácia da comunicação externa é tão importante quanto à interna. Com base na abordagem de Las Casas, 2005, p. 18, acerca dos cinco elementos do composto de comunicação, verifica-se como essas ações estão sendo elaboradas:

a) Propaganda: a relação das ações de propagandas com pernoites é sintetizada na Figura 4:

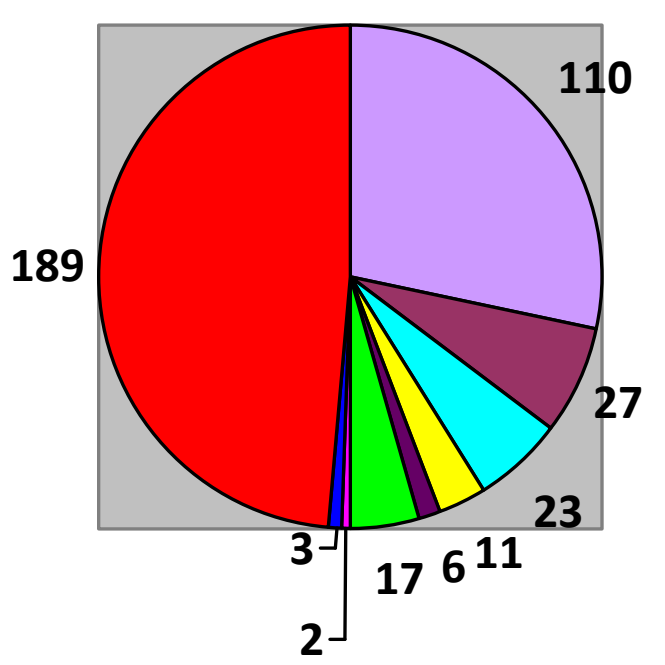

\begin{tabular}{|l|}
\hline Luminoso \\
$\square$ Email \\
$\square$ Internet \\
$\square$ Site da rede \\
$\square$ Guias/Pag. Amarelas \\
$\square$ Outdoor \\
$\square$ Folheteria \\
$\square$ Mala direta \\
$\square$ GDS \\
\hline
\end{tabular}

Figura 4. Estatísticas de pernoites em relação ao veículo de comunicação, propaganda, que a motivou, em um Hotel do interior de São Paulo, no período de 60 dias no ano de 2009.

A propaganda é feita com freqüência em revistas do setor de aviação; jornais on line de grande repercussão; jornais e revistas locais em datas específicas. Ainda há as placas de sinalização em toda cidade indicando como chegar ao hotel; ploters em táxis localizados em pontos estratégicos como rodoviária e aeroporto; outdoor na rodovia e na porta do hotel, sendo este com valor de tarifa promocional. A Rede procura colocar em seus materiais promocionais imagens e ações que atinjam as emoções dos clientes e os toquem com sensibilidade e curiosidade.

$\mathrm{Na}$ Figura 4, a referência ao objeto luminoso, é o painel localizado na frente do Hotel $X$ com o valor de tarifa promocional, para atração de walk ins. Essa ação de comunicação tem grande produção de pernoites e no mix propaganda é a segunda. O painel foi uma das propagandas que o Hotel deixou por meses de fazer uso, por motivos operacionais. Mas ao perceber a importância desse meio recorreu a sua utilização em parceria com o restaurante. Um dos motivos que levou o hotel a 
inutilizar este painel foi em relação ao valor da tarifa impressa no mesmo, que ocasionava reclamações de hóspedes que pagavam valores mais altos.

A equipe de vendas do Hotel, não se agrada com esse meio de comunicação, por evidenciar, também, o valor da tarifa. Em suas várias visitas, clientes questionam: mas e a tarifa do painel na frente do Hotel? Mesmo explicando que é uma tarifa promocional de apenas dois apartamentos, no térreo e single, muitos não entendem e desejam pagar aquele valor.

Os emails são as malas diretas virtuais enviadas para banco de dados, tanto do segmento individual (pessoal no geral) quanto do empresarial, com propagandas do Hotel X ou da Rede. Essa ação é praticada principalmente quando há alguma promoção como de fim de semana, por exemplo.

$\mathrm{Na}$ rede, como no Hotel X, muitas promoções são elaboradas de acordo com a sazonalidade. Dependendo dos eventos e da época do ano, há um maior enfoque em determinado hotel da Rede. Exemplos disso são as feiras como a FRANCAL - Feira Internacional de Calçados, Acessórios de Moda, Máquinas e Componentes - em São Paulo e a FEIARTE - Feira Internacional de Artesanato em Porto Alegre. Faz-se um trabalho específico de hospedagem, mídia especial para os hotéis de Porto Alegre, na FEIARTE e de São Paulo, na FRANCAL. Mas todos os hotéis da Rede têm divulgação o ano todo, onde são desenvolvidas estratégias para atingir o público-alvo em todas as estações. Pois todos os seus empreendimentos são vendáveis durante o ano todo.

A mala-direta virtual funciona a favor do Hotel, pois é eficiente, chega rápido e direto, personaliza, e a pessoa que recebe sente-se mais importante. Mas para isso a mensagem precisa ser clara e ter qualidade para chamar atenção do cliente. As mesmas características da mala-direta virtual têm a não virtual, mas esta não produz tantos pernoites quanto à virtual, conforme verificado na figura 4 .

O Hotel X utiliza essa ação de comunicação, também, para divulgação aos noivos com casamentos marcados. Os cartórios locais fornecem ao Hotel uma listagem com as relações dos casamentos agendados. E esse envia aos casais folders de pacote especial para a noite de núpcias com uma informação de repercussão: a cada vinte apartamentos alugados aos convidados do casamento, o casal ganha o pacote como cortesia.

Essa ação específica tem apresentado um bom efeito. Primeiramente por ser focada para aumentar a demanda de pernoites no final de semana, que 
abrandam pelo Hotel ser voltado para negócios. E, posteriormente por englobar duas ações ao mesmo tempo: mala-direta e indicação. Pois os casais indicarão o Hotel para seus convidados. A ação indicação será melhor discutida no item publicidade.

Mesmo com tantas características a favor da mala-direta, muitas vezes ela é considerada indesejável pelo consumidor, principalmente as virtuais que podem ser consideradas spam (e-mail comercial não solicitado).

A ação pela internet são os sites de reservas on line, como HotelDo, Hóspede Vip e outros. A CMnet é considerada um site de reservas on line mas é mensurada através do item GDS. Essa exclusividade deve-se pela parceria da Rede com a CMnet e pela grande produção de pernoites advindas da mesma, sendo a primeira em relação ao mix propaganda.

Os sites configuram-se como excelentes e eficazes divulgadores da marca. Uma grande vantagem das reservas efetuadas através desses sites é a alavancagem da diária média, pois os apartamentos disponíveis para reservas são em sua maioria de categoria luxo e dependendo da época com tarifas mais altas do que as normalmente praticadas.

Os pernoites gerados pelo site da Rede são em sua maioria clientes que já se hospedaram em demais hotéis da Rede, e quando viajam procuram empreendimentos na localidade de destino. Neste site são encontrados os pacotes promocionais, fotos e informações dos empreendimentos hoteleiros, formulários de reservas on line e as principais novidades e notícias. O comércio eletrônico visa substituir os processos físicos por processos eletrônicos, permitindo uma maior integração da empresa no mercado de negócios.

As páginas amarelas e os guias são os guias de viagens e turismo, como por exemplo, o Guia Quatro Rodas. Mas como forma de mensurar os dados, foi instituído pelo Hotel $X$, que além dos guias também somariam nesses dados as revistas e os jornais. Acredita-se muito no poder da revista, pois é um veículo que fica o ano inteiro à disposição, ou seja, vende muito mais, conforme afirma Andrade (1993, p. 120). Apesar dessa afirmação as propagandas em jornais em revistas são em sua maioria ações coletivas consequentemente institucionais, não gerando grande demanda de pernoites ao Hotel $\mathrm{X}$.

$\mathrm{Na}$ figura 4, o outdoor referido é o que permanece na estrada, na entrada da cidade. Além da divulgação do Hotel X, ele indica como chegar ao Hotel, pois 
informa qual saída seguir. O outdoor possui dois diferentes papéis: sustentação e motivação, então apesar de gerar poucos pernoites é um instrumento de grande importância para a divulgação do Hotel.

A folheteria são pôsteres e folders. Os pôsteres, em sua maioria são dispostos nos elevadores de outros hotéis da rede. O hóspede quando está no elevador acaba lendo-o e mesmo que não utiliza o destino do hotel divulgado, fica conhecendo-o. Os folders são utilizados principalmente dentro dos hotéis, em eventos de interesse turístico e hoteleiro, para envio por mala direta e em visitas realizadas pela equipe da vendas para fortalecer e divulgar a marca.

b) Promoção de Vendas: Uma das formas de promoção de vendas é a participação da Rede em eventos ligados ou não ao turismo.

A participação da rede em eventos pode ser com ou sem estandes próprios. Sem estande próprio a Rede tem como objetivo verificar o desenvolvimento do próprio evento e avaliar as expectativas de novas participações. Com estande próprio, o objetivo principal é atender mercados consolidados e fortalecer a imagem da marca e dos relacionamentos. A Rede avalia os eventos como estratégicos dentro da ação de comunicação, pois se forem planejados criativamente e satisfatórios, além de promover a marca, comercializam e divulgam seus produtos e serviços trazendo um retorno econômico e social.

Alguns eventos que a Rede participa são:

- Feira AVIESTUR (Feira de Turismo da AVIESP - Associação das Agencia de Viagens Independentes do Interior de São Paulo),

- AVIRRP (Encontro Nacional de Agencias de Viagens - Associação das Agencia de Viagens de Ribeirão Preto e Região).

- Feira de Turismo de Gramado, onde há o Festival do Turismo que conta com a participação de 2.600 marcas.

- Rio INTERTUR (Feira Rio Interior de Turismo)

Além de estar presente nas feiras ligadas ao turismo, a Rede e o Hotel X estão presentes em feiras empresariais e de negócio, como Feiras de Noivos, FRANCAL entre outras. A presença destes em eventos é importante para apresentação de seus hotéis, serviços e produtos.

Outros tipos de promoção, como definido por Las Casa (2005) são os brindes, os descontos e as cortesias. As cortesias são oferecidas à clientes que possuem potenciais de reservas em determinado hotel, para que dessa forma 
possam se hospedar e apreciá-lo. A equipe de vendas da Rede tem consigo cortesias para conceder para clientes com potenciais de reservas. Em relação aos brindes, segundo Vavra (1993) eles são importantes para divulgação da marca. A Rede, como o Hotel têm confeccionados brindes que são úteis no dia-a-dia dos clientes, como canetas, blocos de anotação, cadernos com o logotipo do Hotel e endereços dos demais hotéis da Rede, risque-rabisque e outros.

Para estreitar as relações com os investidores, o Hotel, como uma forma de promoção, oferece-lhes tarifas promocionais além do tarifário, no esforço de obter produção neste segmento. Essa ação, como se nota não tem gerado pernoites ao empreendimento. Os investidores, provavelmente, só começarão a utilizar hospedagem do Hotel depois que receberem a distribuição dos lucros. Infelizmente com a crise econômica e com a previsão do Hotel de que a demanda de 2009 figurará com a de 2008, a tendência é piorar e o Hotel tem que elaborar outra forma de conquistá-los.

Outra ação de promoção de vendas é o envio de email para os hóspedes na data de seu aniversário. Ação voltada principalmente para o incentivo da marca, com os mesmos prós e contras da mala direta virtual.

c) Relações Públicas: De acordo com Costa (2009), as relações públicas podem ser estruturadas a partir de uma pesquisa de opinião. Esse levantamento de dados é executado no momento do check-out do hóspede, quando lhe é entregue uma pesquisa de comentários e sugestões do hotel. Assim os serviços prestados devem estar em constantes melhorias, com qualidade, de modo a superar as expectativas do cliente. Em algumas ocasiões ao invés do questionário em mãos, é encaminhado ao hóspede um email no qual ele poderá responder a pesquisa. A idéia do email é mais satisfatória, pois o cliente terá mais tempo para respondê-lo, ao contrário do momento do check-out, onde o hóspede na maioria das vezes está apressado.

Há também a comunicação executada por meio de reuniões e assembléias. As assembléias em sua maioria são realizadas juntamente com os investidores do Hotel X. E, outra forma de relações públicas são as visitas para clientes em potencial, programadas ou não às instalações do hotel e os eventos, conforme abordado por Andrade (1993, p. 140).

Uma ação interessante que o Hotel desenvolve é o café da tarde para as secretárias das empresas com poder de produção de pernoites no Dia das 
Secretárias. Além de fazer a parte social é uma oportunidade de conhecerem o Hotel, os serviços e produtos para posteriormente divulgaram-nos na empresa.

As ações de relações públicas do Hotel $X$ ainda precisam ser melhoradas para ganhar credibilidade. Idéias são várias, mas a concretização dessas ainda estão falhas.

d) Venda direta: como diz Las Casas (2005, p. 250), a venda direta é a forma mais eficaz de marketing. Nota-se que é válida essa afirmação, pois a maioria de pernoites do Hotel $X$ é proveniente da ação de visita da equipe de vendas, conforme sintetizado na Figura 5.

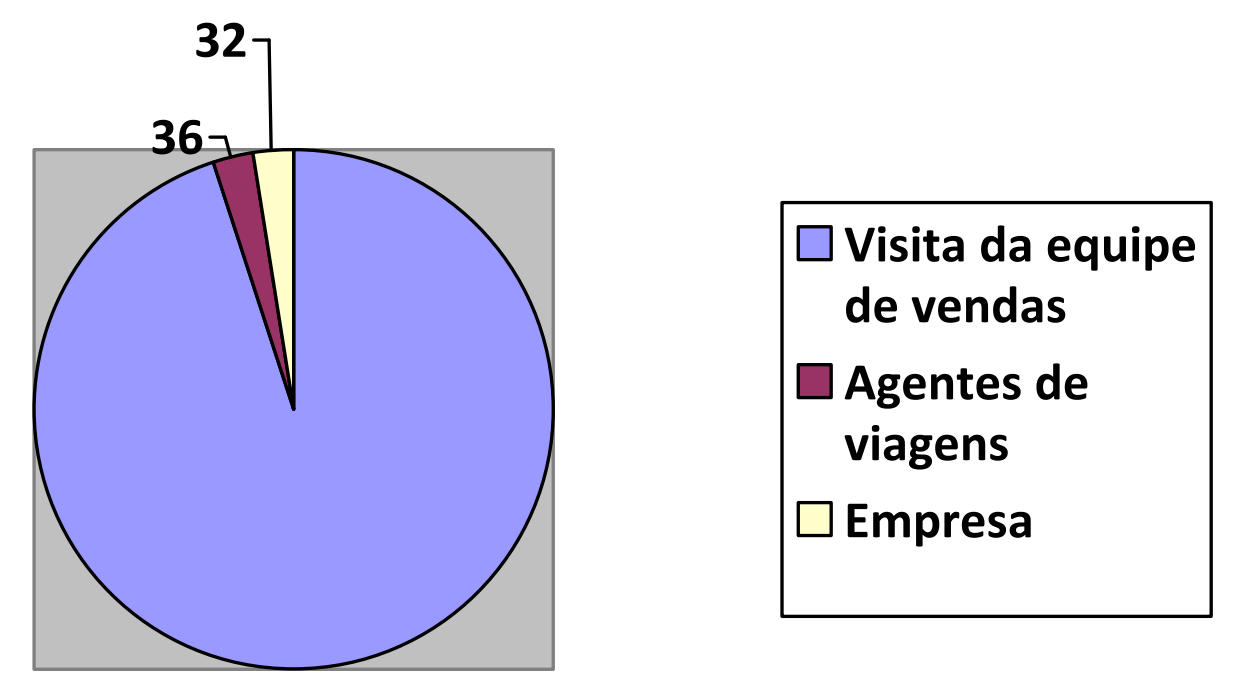

1278

Figura 5. Estatísticas de pernoites em relação ao veículo de comunicação, venda direta, que a motivou, em um Hotel do interior de São Paulo, no período de 60 dias no ano de 2009.

O Hotel X pertence a uma rede hoteleira que conta com uma equipe de vendas de quase cem colaboradores em todo o Brasil. Esses funcionários visitam regularmente agências de viagens, empresas, entidades de classe, organizadoras de eventos, entre outros segmentos. A mentalidade é que todos os vendedores ofereçam e negociem todos os hotéis da rede, pois assim consegue-se maximizar a produção e receita dos clientes. A rede tem em sua base de dados cerca de 30.000 clientes, os quais, em sua maioria estão divididos em carteiras específicas de clientes que são gerenciadas pela equipe de vendas, assim é possível alcançar as 
metas das unidades com muita sinergia entre os mercados, buscando produções de diversas regiões.

Cabe aos colaboradores de vendas a responsabilidade de gerenciar suas respectivas carteiras de clientes, objetivando o crescimento das receitas e incremento da produção da região que atua, bem como, todos os empreendimentos pertencentes a nossa rede.

A rede possui uma empresa coligada, fundada em dezembro de 2002 e na qual é responsável pela venda e divulgação dos hotéis para clientes e mercados específicos. A empresa foi criada com o intuito de preencher uma necessidade de vendas e aproveitar uma oportunidade de mercado onde ainda a rede não tinha presença significativa.

Esta empresa atua, em todo o Brasil, nos segmentos e mercados abaixo:

- FAVECC (Responsável por aproximadamente 23\% das receitas da rede);

- Operadoras de viagens;

- Feiras, Congressos e Eventos (participantes de feiras, congressos e eventos que acontecem por todo Brasil);

- Rio de Janeiro (segundo maior pólo emissor de reservas da rede - apesar de que o Hotel X o segundo pólo é Minas Gerais);

- Bahia;

- Rio Grande do Sul;

- Santa Catarina;

- Mercosul.

O objetivo desta empresa é consolidar e aumentar a participação dos hotéis por ela representados nos mercados/segmentos no qual atua, além de fazer a manutenção dos principais clientes já existentes. Seu intuito é negociar as melhores condições junto a estes nichos de mercados, para a satisfação dos clientes.

A partir de 2006 foi criada uma Campanha de Vendas para estruturar 0 trabalho de vender todos os hotéis da rede. Nesta Campanha foram criadas equipes de trabalho anuais formadas por integrantes de localidades diferentes. A base de trabalho dessa Campanha de Vendas é a carteira de clientes e todos têm como objetivo:

- Identificar sinergia em termos de regiões, carteiras e ou segmentos;

- Melhorar entrosamento; 
- Identificar oportunidades de produtividade;

- Manter carteiras atualizadas;

- Identificar segmentos específicos para melhoria de desempenho;

- Atingir metas estipuladas (produtividade).

A forma de ação de comunicação mais eficaz da Rede é a venda direta.

e) Publicidade: A segunda ação de comunicação que mais tem conduzido os clientes ao hotel é a indicação. Onde apresentou 664 pernoites em sessenta dias. Conforme abordado por Hofman \& Bateson (2003 apud Sergio, 2006), é imprescindível desenvolver uma rede de comunicação boca a boca, ou seja, outros clientes como fontes pessoais de informações reduzem o risco de compra. Uma comunicação boca a boca requer qualidade no serviço que justifique a segurança e confiança do cliente atual em indicar o hotel para um cliente potencial.

É importante ressaltar que além dessas ações a rede em estudo faz parte de alguns programas de fidelização, aprimorando dessa maneira o relacionamento com os clientes e fornecedores (agências de viagens, operadoras, FAVECC, empresas etc). Principalmente no que se refere a vendas on line, onde os programas de fidelização fazem com que os clientes tenham o canal virtual como um negócio atrativo.

Fidelização e captação de clientes são essenciais dentro de uma rede de hotéis. No ato de captar clientes, a Rede aposta na vinculação dos meios de hospedagem aos destinos de viagens. E, além disso, um cliente fidelizado trará para a organização o melhor dos retornos: comentários positivos que chegarão a novos clientes.

A realização das ações de comunicação é importante para que o Hotel alcance o resultado esperado. Mas para que as ações sejam eficientes, há necessidade de planejá-las. O Hotel X juntamente com a Rede elabora o Plano de Ações e Vendas. Este plano é baseado na análise de mercado, do produto e da concorrência, possibilitando aos hotéis ações promocionais, vendas, relações públicas e publicidade com o objetivo de atingir ou superar os resultados estabelecidos para cada estabelecimento. O quadro 10, apresentado anteriormente, é parte desse plano, assim como os quadros 11 e 12 . 
Quadro 11: Planejamento de Ações Segmentadas de Comunicação

\begin{tabular}{|c|c|c|c|}
\hline \multicolumn{4}{|c|}{ FAVECC } \\
\hline NOME DA AÇÃO & DESCRIÇÃO & QTDE & $\begin{array}{l}\text { INVESTIMENTO } \\
\text { (anual) }\end{array}$ \\
\hline Brindes & $\begin{array}{l}\text { Enviar brindes para agradecer } \\
\text { produção de pernoites }\end{array}$ & 100 & $\mathrm{R} \$ 1500$ \\
\hline \multicolumn{4}{|c|}{ EMPRESAS } \\
\hline NOME DA AÇÃO & DESCRIÇÃO & QTDE & $\begin{array}{l}\text { INVESTIMENTO } \\
\text { (anual) }\end{array}$ \\
\hline $\begin{array}{c}\text { Material } \\
\text { promocional }\end{array}$ & Folder & 5000 & $\mathrm{R} \$ 3000$ \\
\hline Fidelização & Brinde Dia das Secretárias & 200 & $\mathrm{R} \$ 2000$ \\
\hline Prospecção & Outdoor na rodovia & 1 & $\mathrm{R} \$ 18.000$ \\
\hline \multicolumn{4}{|c|}{ AGÊNCIAS DE VIAGENS } \\
\hline NOME DA AÇÃO & DESCRIÇÃO & QTDE & $\begin{array}{l}\text { INVESTIMENTO } \\
\text { (anual) }\end{array}$ \\
\hline $\begin{array}{c}\text { Divulgação do } \\
\text { Hotel }\end{array}$ & $\begin{array}{c}\text { Email MKT } \\
\text { (mala direta virtual) } \\
\end{array}$ & 2 & $\mathrm{R} \$ 800$ \\
\hline Fidelização & $\begin{array}{l}\text { Enviar brindes para agradecer } \\
\text { produção de pernoites }\end{array}$ & 100 & $\mathrm{R} \$ 1500$ \\
\hline \multicolumn{4}{|c|}{ EVENTOS E GRUPOS } \\
\hline NOME DA AÇÃO & DESCRIÇÃO & QTDE & $\begin{array}{l}\text { INVESTIMENTO } \\
\text { (anual) }\end{array}$ \\
\hline Prospecção & Mala direta virtual & 3 & \\
\hline \multicolumn{4}{|c|}{ OPERADORAS DE VIAGENS } \\
\hline NOME DA AÇÃO & DESCRIÇÃO & QTDE & $\begin{array}{l}\text { INVESTIMENTO } \\
\text { (anual) }\end{array}$ \\
\hline Brindes & $\begin{array}{l}\text { Enviar brindes para agradecer } \\
\text { produção de pernoites }\end{array}$ & 100 & $\mathrm{R} \$ 1500$ \\
\hline \multicolumn{4}{|c|}{ USUÁRIO DIRETO } \\
\hline NOME DA AÇÃO & DESCRIÇÃO & QTDE & $\begin{array}{l}\text { INVESTIMENTO } \\
\text { (anual) }\end{array}$ \\
\hline $\begin{array}{c}\text { Captação de } \\
\text { Pernoites } \\
\text { Casamento } \\
\end{array}$ & $\begin{array}{l}\text { Cartão Postal/Folders do } \\
\text { Pacote de Núpcias }\end{array}$ & 10000 & \\
\hline Prospecção & Outdoor na rodovia & 1 & $\mathrm{R} \$ 18.000$ \\
\hline $\begin{array}{l}\text { Captação de } \\
\text { Pernoites } \\
\text { Casamento }\end{array}$ & Mala direta & & \\
\hline $\begin{array}{l}\text { Anúncios em } \\
\text { Jornais }\end{array}$ & Divulgação em jornais locais & 12 & $\mathrm{R} \$ 5400$ \\
\hline
\end{tabular}

Fonte: Plano de Ação e Vendas do Hotel X 
O quadro 11 apresenta as ações de comunicação exclusivas do Hotel X juntamente com seu investimento anual. Nota-se nele a ausência de gastos com o painel localizado na frente do hotel. Este está localizado na área pertencente ao Hotel $\mathrm{X}$, consequentemente não paga aluguel do espaço, foi gasto apenas para confecção do mesmo. Essas seriam as ações a serem realizadas, mas não estão definidas a maioria das ações do mix Relações Publicas: reuniões, café da tarde com as secretárias, café da manhã com empresários, cortesias e assembléias com investidores. Essas ações geram custos e deveriam estar planejadas. Em relação à quantidade de cortesias, elas são prenunciadas na tabela de Previsão de Segmento Anual do Planejamento Estratégico do Hotel X, sendo calculados dez pernoites por mês.

Além do planejamento das ações, são traçadas as despesas de cada ação separadas em coletivas e cooperadas trimestralmente como mostra o quadro 12. Os valores investidos deverão ser iguais ao estabelecidos no planejamento orçamentário anual do Hotel X:

Quadro 12: Despesas previstas para o ano de 2009 com ações de marketing coletivas e cooperadas

\begin{tabular}{|c|c|c|c|c|}
\hline $\begin{array}{c}\text { PROPAGANDA E } \\
\text { MARKETING }\end{array}$ & $\begin{array}{c}1^{\circ} \\
\text { TRIMESTRE }\end{array}$ & $\begin{array}{c}2^{\circ} \\
\text { TRIMESTRE }\end{array}$ & $\begin{array}{c}3^{\circ} \\
\text { TRIMESTRE }\end{array}$ & $\begin{array}{c}4^{\circ} \\
\text { TRIMESTRE }\end{array}$ \\
\hline $\begin{array}{c}\text { Comunicação - campanha } \\
\text { corporativa }\end{array}$ & 4471 & 6124 & 5333 & 5500 \\
\hline Ações e mídia - anúncios & 1500 & 1500 & 1500 & 1500 \\
\hline $\begin{array}{c}\text { Comunicação - Ação } \\
\text { eletrônica }\end{array}$ & 600 & 400 & 600 & 600 \\
\hline $\begin{array}{c}\text { Comunicação - Ações } \\
\text { regionais com outros } \\
\text { hotéis }\end{array}$ & 800 & 9000 & 9000 & 9000 \\
\hline $\begin{array}{c}\text { Comunicação materiais } \\
\text { diferenciados }\end{array}$ & 9000 & 900 & & \\
\hline Fotografia & & & & \\
\hline Outros & & & & \\
\hline
\end{tabular}

Fonte: Plano de Ação e Vendas do Hotel X.

Os gastos com comunicação deverão ser planejados para que não se gaste com ações que não trazem resultados e tornam a divulgação massificante.

Além do item Promoção do Marketing Mix, outra forma de divulgação do Hotel seria por outro "P" chamado Processos. A Rede utiliza esse "P" para 0 desenvolvimento de estratégias que melhorem seu relacionamento com os diversos 
públicos. Então, além de preocupar com marketing, serviços, produtos e preço, a Rede é preocupada com a responsabilidade social e a defesa do meio ambiente.

A responsabilidade social é uma das maneiras de exercitar a ética nas relações com clientes, colaboradores, fornecedores, investidores, meio ambiente e comunidade. A Rede pela responsabilidade social buscou por uma causa que unisse todos os empreendimentos e colaboradores, contribuísse com a comunidade para um futuro melhor e que estivesse alinhada a sua estratégia de negócios, colaborando para a sua sustentabilidade no longo prazo. Antes de divulgar a causa e a parceria, foi elaborado um planejamento, através de realizações de reuniões mensais de um grupo de trabalho e acompanhamento das ações.

Após esse planejamento, foi feita uma parceria com uma Instituição (ONG - Organização não Governamental), que uma de suas frentes de atuação, é o enfrentamento à exploração sexual de crianças e adolescentes. Essa Instituição desenvolve programas para a proteção de crianças e adolescentes no turismo, causa adotada como base para a construção do programa de responsabilidade social da Rede.

Os resultados esperados por essa parceira são:

- Rede: reforço da imagem frente aos diversos Stakeholders e a Maximização do investimento social realizado

- Pelo instituto parceiro: divulgação da causa e arrecadação de recursos para projetos e ações estratégicas

- Para a causa: estímulo à criação de novas políticas públicas na área.

A rede para a comunicação interna dessa parceira disponibiliza aos colaboradores manuais de procedimentos na Intranet, treinamentos presenciais e reciclagens via e-learning e cláusula específica nos contratos de trabalho.

A comunicação externa dessa pareceria se apresenta com as seguintes ações:

- Código de Conduta da Rede exposto na recepção dos hotéis;

- Distribuição gratuita de cartões postais sobre a causa para os hóspedes;

- Utilização de todo o Marketing Mix da rede para divulgação da causa, incluindo área específica no site da rede, boletins para 
colaboradores e investidores, press releases, cartazes de elevador, etc;

- Ações especiais no Mês da Criança;

- Divulgação da Parceria em fóruns de discussão, como o Fórum Mundial de Turismo, e em eventos promocionais.

As ações de utilização do Marketing Mix da Rede para divulgar a parceria e a causa para diferentes públicos de interesse são:

- Página de Responsabilidade Social no website da empresa;

- Boletins internos para colaboradores e investidores;

- Cartões-postais com distribuição gratuita para hóspedes (com versão em inglês);

- Pôsteres de elevador;

- Cartões de Natal.

Essa parceira já apresenta resultados de grande importância, como:

- Código de Conduta implementado em todos os hotéis da rede;

- Grande parte dos colaboradores treinados;

- Ação promocional em parceria com empresa de bandeira de cartão de crédito, com geração de $\mathrm{R} \$ 57$ mil para determinado projeto;

- Três Leilões Silenciosos, com arrecadação total de $\mathrm{R} \$ 130$ mil para projetos apoiados pelo instituto e para a continuidade das ações da parceria;

- Apresentação da parceria como caso de sucesso em fóruns do setor de Turismo;

- Caso reportado internacionalmente;

- Fidelização de clientes.

Os resultados já alcançados pela parceria demonstram seu grande potencial, tanto no que diz respeito à implementação do Código de Conduta, quanto às ações de marketing relacionado a causas.

Com esses resultados espera ter um Turismo Sustentável e Proteção de Crianças e Adolescentes devido à exploração sexual. Turismo Sustentável é aquele que respeita não só o meio ambiente, mas também a comunidade. A exploração sexual de crianças e adolescentes é uma prática criminosa, que a sociedade não tolera, e depende de cada um de nós o compromisso e a obrigação de nos 
manifestarmos preventivamente. A infância é um dos elos mais frágeis da cadeia de relações do turismo, pois há incidência de exploração sexual. 


\section{Conclusão}

Esse estudo teve como questões de pesquisa: Como são desenvolvidas as ações de comunicação de um hotel de rede internacional, para a captação e fidelização de clientes? Estão as ações de comunicação integradas em uma estratégia ou são feitas de forma pontual e dispersa?

Tratando-se das estratégias, observou a existência tanto na Rede quanto no Hotel $X$ de uma área de marketing estruturada e especializada, com excelência administrativa e sintonia com o mercado. Embora haja situações que precisam ser melhoradas.

$\mathrm{Na}$ ferramenta propaganda, o item outdoor chama a atenção, pois resulta em apenas dezessete pernoites e é a ação de comunicação que mais custa para o Hotel, sendo $R \$ 18.000,00$ por ano. Mas por ser um instrumento importante que lembra a marca, o Hotel ao invés de inutilizá-lo, poderá procurar outro ponto de inserção ou talvez a mudança de layout do mesmo.

Observa-se a necessidade das Relações Públicas, serem mais bem trabalhada, através de um conjunto de ações, além de desenvolver canais de comunicação eficientes com o público-alvo. Isso é conseqüência dessas ações não constarem no Plano de Ação e Vendas do Hotel, portanto não estão planejadas.

Outro dado que chama a atenção é em relação às estatísticas de veículos de comunicação, no item agentes de viagens. A produção de pernoites dos veículos de comunicação em relação ao segmento de origem das reservas, agência de viagens, são opostas, o que caracteriza que os agentes não têm divulgado o Hotel aos seus clientes. E sim os clientes têm solicitado a reserva no Hotel específico.

Sente-se, então a necessidade de um trabalho exclusivo no segmento agência de viagens, principalmente através da equipe de vendas. Para que dessa forma consiga estreitar as relações e entender o motivo da pouca divulgação do Hotel X e da Rede.

Com isso, nota-se que a Rede deve analisar melhor os segmentos que pretende atingir. A descoberta dos interesses, desejos e expectativas dos seus públicos-alvo faz com que o empreendimento viabilize uma comunicação estrategicamente planejada que atinja a todos de forma dirigida, possibilitando 0 fortalecimento e a legitimação de sua imagem. A melhor definição do segmento a atingir resulta no melhor posicionamento do empreendimento. 
Mas falta posicionamento do Hotel em relação a sua característica. Ou seja, o hotel possui a maior tarifa média em relação aos seus concorrentes, mas é um Hotel de rede internacional, têm os melhores serviços e produtos, isso agrega valor. A lembrança ao cliente de ser um Hotel internacional é pouco enfatizada pelo mesmo.

A Rede e o Hotel X poderiam estar melhor investindo no segmento de vendas diretas, devido a quantidade de pernoites geradas ser bem superior, resultando em mais de $50,0 \%$ dos pernoites do Hotel.

Em relação ao mercado, o fato da participação do Hotel $X$ ser inferior à concorrência e os acionistas estarem insatisfeitos, tem pouca ligação com as ferramentas de comunicação, pois esses resultados são principalmente atribuídos por causa da diária média oferecida pelo Hotel. A diária é superior ao da concorrência, fazendo que até os investidores não usufruam do Hotel. Mas é importante salientar que ao se relacionar a taxa de ocupação média com a tarifa média, o Hotel $\mathrm{X}$ tem uma rentabilidade maior que os seus concorrentes.

Os objetivos da pesquisa foram: analisar as ações de comunicação, verificando a eficiência de cada uma para se atingir os objetivos; comparando-as com o referencial teórico e assim analisando como são mensurados os resultados dessas ações, bem como a relevância de cada uma delas.

Para se alcançar efetivamente os objetivos propostos, além das entrevistas informais com gestor e funcionários do Hotel, foi necessária a análise de diversos documentos e dados oferecidos pelo empreendimento. A falta das entrevistas pessoais e dos questionários, com a percepção dos gestores e funcionários e dos clientes respectivamente, nesse tipo de estudo, implicou em um retrato menos legítimo dos processos de ação de comunicação na prática.

Verificando os resultados constatou-se que a comunicação interna é participativa e considerada uma área vital e integrada ao conjunto de estratégias e objetivos organizacionais. Acredita-se que uma comunicação interna participativa envolve o funcionário nos assuntos da organização e nos fatos que ocorrem na sociedade.

A comunicação externa da Rede e do Hotel X é estruturada e planejada. Quanto à sinalização da comunicação visual dos hotéis da rede, não seguem uma padronização cromática e formal, imprimindo cada layout diferentemente de outros. Para tanto, os canais são adequados às regiões em que se encontram os 
empreendimentos, respeitando hábitos, costumes regionais e o compromisso social. Ficando claro o interesse da Rede em harmonizar o relacionamento com os diferentes públicos, atuando em parcerias com estratégias que melhorem a convivência com as comunidades onde se inserem.

A Rede preocupada com a responsabilidade social fez parceria com um Instituto (ONG). Com certeza, esse tipo de sociedade ao longo tempo será de grande fator para sua credibilidade, pois o consumidor de hoje, se posiciona como sendo um indivíduo mais envolvido com as questões sociais, ambientais e étnicas. As ações para divulgação dessa parceria e da causa resultam em marketing para a própria rede.

Verificou-se que a realização de ações de comunicação nas organizações hoteleiras torna-se cada vez mais necessária devido à exigência dos consumidores em buscar diferentes e satisfatórios produtos/serviços e também pela forte concorrência encontrada nesse setor.

Assim, com as possibilidades de discussão de idéias, trocas e diálogos que a comunicação mercadológica propicia, acredita-se que a Rede possui canais para manter adequadamente seus padrões de bom atendimento. Os diversos programas e estratégias de comunicação empregadas pela Rede fortalecem sua imagem e atingem os desejos de seus hóspedes.

Identificou-se que a atuação das ações de comunicação e iniciativas trabalhadas pelo empreendimento, além de gerenciar informações corretas do Hotel para seus públicos internos e externos, visam à consolidação no mercado e estabilização de seu compromisso com seus públicos, fazendo a administração deste atuar corretamente e contribuir positivamente para alcançar seus objetivos.

Do mesmo modo, constata-se que através das ações mercadológicas, a Rede consegue gerar um diferencial e se destacar frente aos seus concorrentes. Nesse contexto, reafirma-se que as organizações hoteleiras necessitam planejar e investir em ações de comunicação para que seus objetivos organizacionais sejam plenamente atingidos. 
REFERÊNCIAS BIBLIOGRÁFICAS (Segundo a NBR 6023:2002 da ABNT)

ALBRECHT, Kal. Revolução nos serviços: como as empresas podem revolucionar a maneira de tratar os seus clientes. Tradução de Antonio Zoratto Sanvicente. 6. ed. São Paulo: Pioneira, 2000.

AMAZONAS, Eny e GOLDNER, Lilian. Estudo raio $X$ da hotelaria brasileira: as redes hoteleiras do Brasil. 2004. CD - ROM apud ABIH. Novos rumos da hotelaria. Disponível em: <http://www.abih.com.br/principal/historia.php?cod=009>. Acesso em 20 fev 2009.

ANDRADE, Cândido Teobaldo de Souza. Para entender Relações Públicas. São Paulo: Edições Loyola, 1993.

ANSARAH, M.G.R. (org.). Turismo: segmentação de mercado. 3 ed. São Paulo: Futura, 1999.

ARTEAGA, R. Hoteleiros opinam sobre a influência da crise no trade. Hotelier news. $\quad 9 \quad$ out 2008 . Disponível em: < http://www.hoteliernews.com.br/HotelierNews/Hn.Site.4/NoticiasConteudo.aspx?Noti cia $=46224 \&$ Midia $=1$ >. Acesso em 12 abril 2009.

BENI, M. C. Análise estrutural do turismo. 12.ed. São Paulo: SENAC, 1998.

BURNS, Peter M. Turismo e Antropologia: uma introdução. São Paulo: Choronos, 2002

CASSAR, M. Estratégias de marketing para hotelaria. In: DIAS, R.; PIMENTA, M. A. (org). Gestão de hotelaria e turismo. 1.ed. São Paulo:Pearson Prentice Hall, 2005.

CERVO, A.L.; BERVIAN, P. A. Metodologia científica. 4. ed. São Paulo: Makron Books, 1996.

. Metodologia científica. 5. ed. São Paulo: Prentice Hall, 2002.

COBRA, M. Estratégias de marketing de serviços. 2 ed. São Paulo: Cobra Editora, 2001a.

Marketing de turismo. 1. ed. São Paulo: Cobra Editora, 2001b.

COOPER et al. Turismo, princípios e prática. 2 ed. Porto Alegre: Bookman, 2001

COSTA, A. Relações públicas e hotelaria. Disponível em: < http://www.mundorp.com.br/alexandre.htm>. Acesso em 10 abril 2009.

CRESCITELLI, E.; IKEDA, A.A. Marketing de relacionamento de fabricantes e vendedores de varejo. Disponível em: < http://revistas.pucsp.br/index.php/rad/article/viewFile/462/387>. Acesso em 12 abril 2009. 
DENCKER, Ada de F. M. (org.). Planejamento e Gestão em Turismo e Hospitalidade. São Paulo: Editora Pioneira Thomson Learning, 2004.

FACHIN, O. Fundamentos de metodologia. 3. ed. São Paulo: Saraiva, 2001.

FORTES, Waldyr Gutierrez. Relações Públicas: processo, funções, tecnologia e estratégias. 2. ed. rev. e ampl. São Paulo: Summus, 2003.

FOWLER, F.R. Marketing estratégico e estratégia competitiva: um modelo integrado de analise e sua aplicação em um caso. 2002. 63f. Plano de Tese (Doutorado) -USP- FEA, São Paulo, SP, 2002.

GIL, A.C. Como elaborar projetos de pesquisa. São Paulo: Atlas, 2002. 175 p.

GIACOMINI FILHO, G. Marketing: conteúdo, didática e perspectiva. In: TRIGO, M.G.R. (Org.). Como aprender turismo como ensinar. v. II. São Paulo: Senac, 2004. p. 203-228.

GRONROOS, C. Marketing gerenciamento de serviços: a competição por serviços na hora da verdade. Rio de Janeiro: Campus, 1995.

GUIMARAES, C.T.; MILANI, G.N.F.; CRESCITELLI, E. Aplicação de ações de marketing de relacionamento em lojas de departamento. Disponivel em: < http://www.ead.fea.usp.br/Semead/8semead/resultado/trabalhosPDF/57.pdf>.

Acesso em 12 abril 2009.

HOOLEY, G.J.; SAUNDERS, J.A. e PIERCY, N.F. Estratégia de marketing e posicionamento competitivo. 3 ed. São Paulo: Pearson Education do Brasil, 2006.

Interlink Hotels. Disponível em: < http://www.interlinkhotels.com.br/hotelaria/gds.htm>. Acesso em 11 abr 2009.

KOTLER, P. e ARMSTRONG, G. Princípios de marketing. 5 ed., Rio de Janeiro: Prentice-Hall, 1993.

Livros Técnicos e Científicos Editora, 1999.

Princípios de Marketing. 7. ed. Rio de Janeiro:

KOTLER, P. Administração de marketing: análise, planejamento, implementação e controle. 5. ed. São Paulo: Atlas, 1998.

Administração de Marketing: a edição do novo milênio. 10.ed. São Paulo: Prentice Hall, 2000.

KRIPPENDORF, J. Sociologia do turismo: para nova compreensão do lazer e das viagens. São Paulo: Aleph, 2001.

KUAZAQUI, E. Marketing turístico e de hospitalidade. São Paulo: Makron Books, 2000. 
LAGE, B.H.G.; MILONE, P.C. Economia do turismo. 6 ed. Campinas: Papirus, 1991.

LARA, S.B. Marketing e vendas na hotelaria. 1 ed. São Paulo: Futura, 2001. 184 p.

LAS CASAS, Alexandre Luzzi. Marketing: conceitos, exercícios e casos. São Paulo: Atlas, 2005.

LESLY, Philip. Os fundamentos de relações públicas e da comunicação. São Paulo: Pioneira Thomson Learning, 2002.

LITTLE, A.D. Como transformar seu produto em mania. HSM Management. n. 48. p. 63-68, 2005.

LOVELOCK, C. H.; WRIGHT, L. Serviços: marketing e gestão. São Paulo: Saraiva, 2005.

MALHOTRA, N. K. M. Pesquisa de marketing: uma orientação aplicada. 3. ed. Porto Alegre: Bookman, 2001.

MAXIMIANO, A. C. A. Introdução à administração. 5. ed. São Paulo: Atlas, 2000.

MEDLIK, S. e INGRAM, H. Introdução à hotelaria: gerenciamento e serviços. 4. ed. Rio de Janeiro: Campus, 2002.

MELO NETO, Francisco Paulo de; FROES, César. Gestão da responsabilidade social corporativa: o caso brasileiro. Rio de Janeiro: Qualitymark, 2001.

MIDDLETON, Victor T. C. Marketing de turismo: teoria e prática. 3 ed. Rio de Janeiro: Elsevier, 2002.

MOTA, K.C.N. Marketing turístico: promovendo uma atividade sazonal. 1 ed. São Paulo: Atlas, 2001.

MUNIZ, P. Hoteleiros opinam sobre a influência da crise no trade. Hotelier news. $\quad 9$ out 2008. Disponivel em: http://www.hoteliernews.com.br/HotelierNews/Hn.Site.4/NoticiasConteudo.aspx?Noti cia=46224\&Midia=1 >. Acesso em 12 abril 2009.

O'CONNOR, P. Distribuição da informação eletrônica em turismo e hotelaria. São Paulo: Bookman, 2001.

OLIVEIRA, G.H. Serviço ao cliente como estratégia de marketing nos hotéis 4 e 5 estrelas de Foz do Iguaçu. 2001. 98f. Dissertação (Mestrado em Administração com ênfase em Marketing). Universidade Federal do Rio Grande do Sul - Porto Alegre - RS, 2001

Organização Mundial do Turismo. Introdução ao turismo. 1. ed. São Paulo. Roca, 2001. . 
PELLEGRINI FILHO, Américo. Dicionário enciclopédico de ecologia e turismo. São Paulo: Manole, 2000.

PIRES, V.C. A evolução da comunicação boca-a-boca. RIMAR - Revista Interdisciplinar de Marketing. v.2, n.1, p. 35-47, 2003

RICHARDSON, R. J. Pesquisa social. 1. ed. São Paulo: Atlas, 1999.

RUSCHMANN, D. Marketing turístico: um enfoque promocional. 1. ed. Campinas:Papirus, 1999.

SANTOS, D.G.; MATTAR, F.N. Uma contribuição ao estudo do processo de planejamento empresarial: Uma proposta de modelo para o planejamento de marketing. Disponível em: < http://www.ead.fea.usp.br/semead/3semead/pdf/Marketing/Art005.PDF > Acesso em 04 abril 2009.

SERGIO, L.R.B. Ações de comunicação de marketing em clínicas veterinárias para animais domésticos: estudo de casos na cidade do Rio de Janeiro. 2006. 155f. Dissertação (Mestrado Profissional em Administracao). Faculdade De Economia E Finanças IBMEC. Faculdades IBMEC. Rio de Janeiro - RJ, 2006.

SIQUEIRA, Antonio Carlos Barroso de. Marketing Industrial: Fundamentos para a ação Business to Business. São Paulo: Atlas, 1992.

Soluções Informática. 16 anos trabalhando exclusivamente para área hoteleira. Disponível em:

http://74.125.47.132/search?q=cache:eBxciyB0_VMJ:www.managercorp.com.br/Dow nload/prospecto.doc + pool+hoteleiro $\& \mathrm{~cd}=2 \& \mathrm{hl}=\overline{\mathrm{pt}}-\mathrm{BR} \& \mathrm{ct}=\mathrm{clnk} \& \mathrm{gl}=\mathrm{br}>$. Acesso em 11 abr. 2009.

VAVRA, T.G. Marketing de relacionamento. 3. ed. São Paulo: Atlas, 1993.

VAZ, G. N. Marketing turístico: receptivo e emissivo: um roteiro estratégico para projetos mercadológicos públicos e privados. 1. ed. São Paulo: Pioneira, 1999.

VIERA, E.V. Marketing hoteleiro: uma ferramenta indispensável. Caxias do Sul: Educs, 2003.

VIERA, E.V. Qualidade em serviços hoteleiros: a satisfação do cliente é função de todos. Caxias do Sul: EDUCS, 2004.

WEBSTER, F. E. The future role of marketing in the organization. In: LEHMANN, D. R.; JOCK, K. E. (eds.) Reflections on the futures of marketing, Cambridge, MA: Marketing Science Institute, 1997.

WESTWOOD, John. O plano de marketing. São Paulo: Makron Books, 1996. 
WHITELEY, R. A. A empresa totalmente voltada para o cliente. Rio de Janeiro, Campus, 1999.

YIN, R. Estudo de caso: planejamento e métodos. Porto Alegre: Bookman, 2005.

ZENONE, Luiz Cláudio e BUAIRIDE, Ana Maria Ramos. Marketing da Comunicação. São Paulo: Futura, 2002. 